\title{
SMEs with legally restricted banking access: evidence from the US marijuana industry
}

\author{
Markus Merz ${ }^{1}$ (D) $\cdot$ Jan Riepe $e^{1,2}$ (D)
}

Accepted: 9 October 2020 / Published online: 1 March 2021

(c) The Author(s) 2021

\begin{abstract}
This paper examines how legally restricted access to banking services affects small and medium-sized enterprises (SMEs) in a highly developed country. Using a mixed-method approach, we examine the unique situation of the US marijuana industry. The industry benefits from the superior institutional environment in terms of legal protection and the labor market of the United States. However, due to conflicting state and federal laws it has no legal access to banking. We find significant value effects around three major events that affected future access to banking. These results indicate that banking access remains desirable for the marijuana industry. A survey taken by marijuana SMEs provides insights into what banking services are considered most valuable. We find that marijuana SMEs have problems to obtain financing and handle their transactions largely in cash, resulting in transaction inefficiency and high security concerns. Thereby, we shed light on the value of banks for SMEs in developed countries. We complement the literature on financial transaction services by highlighting the value for SMEs in developed markets.
\end{abstract}

Keywords Access to banking · Financial development $\cdot$ Small and Medium-sized enterprises $\cdot$ Marijuana firms

JEL Classification D22 - G21 $\cdot$ M13 $\cdot$ M21 $\cdot$ O16 $\cdot$ O43

Markus Merz

markus.merz@uni-tuebingen.de

Jan Riepe

j.riepe@uni-tuebingen.de; jan.riepe@uni-paderborn.de

1 Department of Banking, Eberhard-Karls University of Tuebingen, Nauklerstr. 47, 72074 Tuebingen, Germany

2 Faculty of Business Administration and Economics, University of Paderborn, Warburger Str. 100, 33098 Paderborn, Germany 


\section{Introduction}

Banks are a vital lifeline for the economy (Bernanke 2008). They supply capital to firms and facilitate the exchange of goods and services (Levine 1997, 2005; Levine et al. 2000; Song and Thakor 2010). In addition, they offer safekeeping depository services (Donaldson et al. 2018). While in developed countries, capital markets and other non-bank financial intermediaries also fulfill these functions, a large number of studies have shown that access to bank financing is still crucial for firms (e.g., Jayaratne and Strahan 1996; Bertrand et al. 2007; Beck et al. 2008 and Huber 2018). This holds particularly true for small- and mediumsized enterprises (SMEs) in developing countries (compare, e.g., Ayyagari et al. 2013 for an in-depth literature overview). More recently, however, an increasing number of studies also convincingly established the importance of bank financing for SMEs in developed countries (e.g., Krishnan et al. 2014; Robb and Robinson 2014; Fracassi et al. 2016 and Berg 2018). While all of these studies find that banks are crucial for financing, the other banking services remained unconsidered. Specifically, payment and financial transaction services are known to be an essential banking function (Kohn 1999; Donaldson et al. 2018). In their theory of banking, Donaldson et al. (2018) even cite safekeeping depository services as a fundamental aspect of banks. However, there are only a limited number of empirical findings from developing countries, most of which focus on the Kenyan mobile money market. In this famous example, financial transaction services from M-Pesa are considered. This service enables customers who have limited or no access to a bank account to send, receive, and store money. Overall these studies show the importance of access to payment and financial transaction services. Vaughan (2007), for example, reports that individuals use the mobile payment service to store money safely when traveling across Kenya. Jack and Suri (2014) provide evidence that access to financial transaction services affects the risk-sharing behavior of households. In particular, when faced with a financial shortage, households with access to transaction services are more likely to receive support from their network of family and friends. Plyler et al. (2010) and Beck et al. (2018) find that access to financial transaction services is not only welfare-enhancing on the household level, but also growth-enhancing for SMEs. Additionally, Beck et al. (2018) show empirically that access to financial transaction and payment services also influences access to external lending. Considerably less is known about the value of bank-based transaction services in highly developed countries. Examples of firms in developed countries without banking access are limited.

Our study aims at filling this knowledge gap by using the unique situation of the US marijuana industry. While this industry has access to all other economic infrastructure, such as the legal system and the labor market, federal law inhibits the marijuana industry from using the traditional banking system (see Hill 2015). In the United States, however, new alternative financial intermediaries from the digital world (FinTechs) additionally exist (Ventura et al. 2015; Mills and McCarthy 2016). These intermediaries frequently offer clients faster and more flexible 
solutions at good rates, such as instantaneous payment services, reliable information tracking, and new borrowing technologies. This calls into question whether in this setting traditional banks still play a significant role. To understand the perceived importance of banking access for the US marijuana industry in general, we apply an event study. We conduct event studies on three major occasions that affect the marijuana firms' probability of gaining legal access to banking services. Using a mixed-method approach, the event study results are complemented by a detailed survey among marijuana SMEs (microbreweries serve as a control group). With our survey, we reassess the legally restricted access to banking for unlisted firms. We specifically concentrate on the perceived business challenges that arise from the legally denied access to banking in a developed country for SMEs. Based on the literature, we would expect that financing by traditional banks is highly desirable for the SMEs of the marijuana industry. Although in developing countries, it has been shown that transaction services are beneficial, in the United States alternative transaction methods to traditional banks exist. Therefore, using the results of the survey, it will be identified if transaction services by traditional banks are still considered relevant.

\section{The marijuana firms and the banking system}

In the United States, marijuana is considered a Schedule I drug. This means that according to the Controlled Substance Act, it is federally illegal to possess, use, buy, sell, or cultivate marijuana. This prohibition also includes providing banking services to marijuana firms. Despite its federal controlled substance status, the medical and recreational possession, use, sale, and cultivation of marijuana has been legalized in some states. In January 2014, Colorado became the first state where licensed and regulated retail stores could sell recreational marijuana to consumers. This jump-started a new industry. Washington State, Alaska, and Oregon soon followed suit. As of December 2019, eleven states have legalized recreational marijuana. About $70 \%$ of the US population now lives in states where retail and/or medical marijuana is allowed. According to Marijuana Business Daily ${ }^{\mathrm{TM}}$ (2019), industry sales in the United States increased from about $\$ 2.7$ billion in 2014 to up to $\$ 14$ billion in 2019. Figure 1 shows the legal status of marijuana sales in each state.

Although marijuana is legalized to some extent in several states, the Department of Justice has made clear that "[p]ersons who are in the business of cultivating, selling or distributing marijuana, and those who knowingly facilitate such activities, are in violation of the Controlled Substance Act, regardless of state law" (Cole 2011 , p. 2). In other words, regardless of contradictory legal status at a state level, individuals, firms, and financial institutions that violate the Controlled Substances Act can be federally prosecuted. While a local marijuana firm can operate according to the legal requirements of a single state, federal law directly affects banks. Although the United States' dual banking system allows for both federal- and state-chartered institutions, the vast majority of financial institutions are federally 


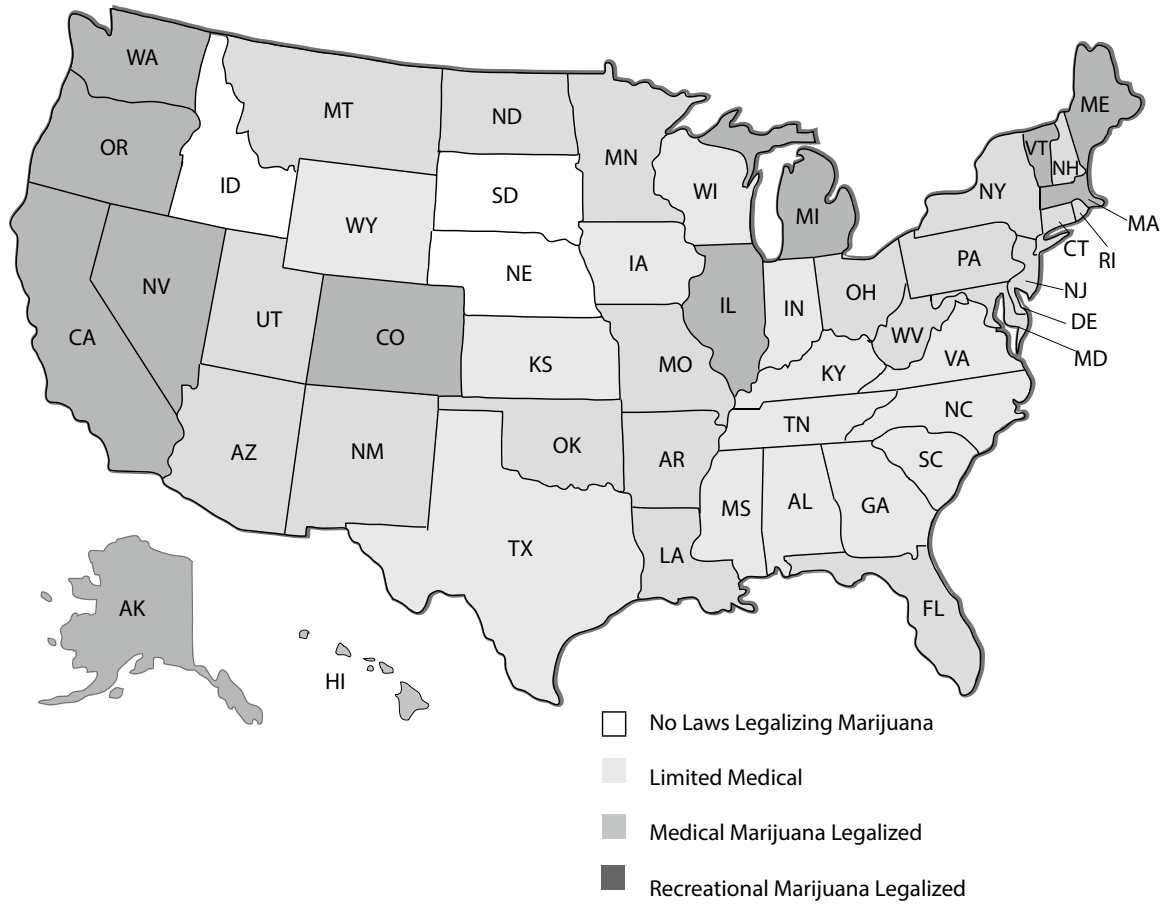

Fig. 1 Marijuana laws by state, as of December 2019

insured (FDIC). ${ }^{1}$ With the benefit of federal insurance comes the burden of federal regulation.

There are additional legal requirements that intensify the legal threat to financial institutions. As outlined in the Bank Secrecy Act (1970) and the Money Laundering Control Act (1986), federal law requires all financial institutions to report any illegal activity to federal officials and to prevent wrongdoers from accessing the banking system. In the words of Hill (2015, p. 617), "a financial institution that knowingly processes transactions for marijuana-related businesses commits the crime of money laundering." Any wrongdoing can cause civil and criminal penalties for financial institutions ranging from costly fines to the complete closing of the institution. Anecdotal evidence in the Marijuana Business Daily ${ }^{\mathrm{TM}}(2015$, p. 7) indicates that "most banks [...] will not move forward until the government issues actual new rules or changes the law."

On February 14, 2014, the Department of Justice and the Department of the Treasury's Financial Crime Enforcement Network (FinCEN) took a step towards easing the ban on marijuana firms from the banking system. They jointly issued

\footnotetext{
${ }^{1}$ Even banks that operate under state charter rather than national charter use the Federal Reserve system for transferring funds and are generally supervised by the Federal Reserve, the National Credit Union Administration, or the Federal Deposit Insurance Corporation.
} 
Guidance Fin-2014-G001, which describes how banks should handle marijuanarelated clients (Cole 2014; Department of the Treasury Financial Crimes Enforcement Network 2014) and announced their general intent to not prioritize the punishment of banks engaging in business relationships with legal marijuana firms. The guidance was perceived by market participants as a first step towards enabling banking access for marijuana firms (Hill 2015) giving hope that the legal restrictions would soon be abandoned altogether.

After the issuance of the Guidance Fin-2014-G001, the Fourth Corner Credit Union (FCCU) was founded with the mission to provide banking services to marijuana firms. Despite initially appearing promising, the US District Court's ruling in Denver on January 5, 2016 ended the FCCU's attempt to receive a Master Account for electronic money transactions and payment services with the Federal Reserve, hindering a fast change in the legal situation. In their ruling, the court prioritized the federal law over the Guidance Fin-2014-G001 and reiterated that banks are not legally allowed to have clients from the marijuana industry. The court's decision not only immediately affected the FCCU, but also had declaratory power for all other financial service providers in the United States.

On September 25, 2019, in a new attempt to harmonize federal and state law, the Secure and Fair Enforcement (SAFE) Banking Act was passed with a resounding 321-103 vote in the Federal House of Representatives. While the passing of the SAFE Banking Act in the House was a first step enabling banking access, concerns that marijuana businesses violate federal laws were not fully addressed. "Ultimately, the only federal action that could provide equitable financial services to the industry is a change in federal treatment of [...] marijuana" (Lawrence 2019, p. 31). The initial euphoria of the marijuana industry about the landmark US House vote was dampened as it remained unclear how the Senate would vote and if President Trump would even sign it into law.

\section{Data and method}

\subsection{Empirical strategy}

To explore the importance of banking services for marijuana firms, e.g., financing and financial transaction services, we apply a mixed-method approach. To measure the necessity of banking services for the marijuana industry as a whole, we use the event study method. As events, the issuing of the Guidance Fin-2014-G001 regarding marijuana enforcement, the US District Court's unexpected ruling in 2016 and the US House of Representatives vote on the SAFE Banking Act in 2019 were selected. All events mark milestones in the marijuana industry's fight to gain legal access to the banking system (Chiang 2017; Lawrence 2019). We expect to find positive (negative) abnormal returns for events that increase (decrease) the likelihood of banking access, if market participants perceive banking services as important for the marijuana industry. To specifically understand the perspective of SME members of the marijuana industry on the importance of legal bank access, a detailed survey was conducted. As a control, similarly sized microbreweries were surveyed. Similar 
to marijuana firms, microbreweries face multiple regulations at the federal and state level with respect to producing, distributing, and selling their products (Anhalt 2016). However, in contrast to marijuana firms, microbreweries have legal access to banks. Conveniently, they became popular in similar areas and at around the same time as marijuana was legalized (Elzinga et al. 2015; Brewers Association 2017). Both microbreweries and marijuana firms belong to sin industries and as a result share a number of other characteristics. Hong and Kacperczyk (2009) and Durand et al. (2013) show that in general sin firms have similar investors, receive less coverage from analysts and face greater litigation risk. We expect that if banking services are perceived as valuable for sin firms, respondents from the marijuana industry should more often than microbreweries identify the lack of bank-related services as challenging. With the survey, we specifically examine the desirability of (a) transaction and payment services and/or (b) bank lending for these industries. Based on the literature that has established the crucial role of access to bank financing, we expect that our respondents have a particular desire for bank financing.

\subsection{Event study}

For the event study, we identified all listed US firms that engage in marijuanarelated business activities based on the Bloomberg Weed Index, firms mentioned in the 2014 and 2015 Viridian Cannabis Industry Report, and firms mentioned by Weisskopf (2019). It was manually verified that all firms conduct business in the marijuana industry. Overall, 87 firms from the marijuana industry that were listed on a stock exchange were identified. Thomson Reuters Datastream provided the corresponding stock prices for the marijuana firms. All time series are adjusted for nontrading days. We deleted penny stocks below 10 cents and illiquid stocks that are traded on less than $20 \%$ of all trading days within the respective estimation window. We also deleted stocks with less than 30 non-zero daily returns per year or missing return observations in the 20 days before the respective event (Brown and Warner 1985). Additionally, we did not consider returns above $100 \%$ or equal to $-100 \%$ on a single trading day and the subsequent reversals. Applying all of these criteria resulted in a sample of 28 firms for the first event, a sample of 28 firms for the second event and a sample of 30 firms for the third event. Overall, 52 unique marijuana firms were considered. Some firms were considered in more than one event. A detailed list of all firms included in the samples by marijuana industry activities and by stock exchange listings is provided in Tables 11 and 12 in Appendix 1.

All samples consisted of firms within several marijuana industry activities, such as growers, providers and manufacturers of equipment or growing facilities, and more indirectly, firms that provide supplementary goods or services. While some of the firms were newly founded, other firms in the sample previously operated in other industries before becoming marijuana firms, such as suppliers. With the exception of the producers, each sample's distribution closely resembles that of the marijuana industry. In all samples, a high number of firms were engaged in pharmaceutical research that includes marijuana firms which distribute their products for medical purposes. While medical marijuana is legal in many states, 
Table 1 Descriptive statistics event study

\begin{tabular}{lclllll}
\hline & $\mathrm{N}$ & Mean & St. dev & P25 & Median & P75 \\
\hline Event 1 & & & & & & \\
Number of employees & 23 & 38 & 72 & 4 & 7 & 38 \\
Revenues [in million \$] & 28 & $\$ 9.27$ & $\$ 23.79$ & $\$ 0.00$ & $\$ 0.12$ & $\$ 5.38$ \\
Total assets [in million \$] & 28 & $\$ 19.89$ & $\$ 65.40$ & $\$ 0.05$ & $\$ 1.52$ & $\$ 7.10$ \\
Market cap [in million \$] & 28 & $\$ 184.61$ & $\$ 346.48$ & $\$ 21.53$ & $\$ 55.38$ & $\$ 176.99$ \\
Portfolio returns & 239 & $0.86 \%$ & $2.78 \%$ & $-1.03 \%$ & $0.39 \%$ & $2.57 \%$ \\
Event 2 & & & & & & \\
Number of employees & 28 & 46 & 109 & 4 & 10 & 21 \\
Revenues [in million \$] & 28 & $\$ 18.55$ & $\$ 62.86$ & $\$ 0.08$ & $\$ 0.53$ & $\$ 10.17$ \\
Total assets [in million \$] & 28 & $\$ 33.99$ & $\$ 78.25$ & $\$ 1.47$ & $\$ 3.70$ & $\$ 25.89$ \\
Market cap [in million \$] & 28 & $\$ 123.51$ & $\$ 407.37$ & $\$ 7.01$ & $\$ 10.03$ & $\$ 22.85$ \\
Portfolio returns & 239 & $-0.11 \%$ & $1.92 \%$ & $-1.39 \%$ & $-0.22 \%$ & $1.14 \%$ \\
Event 3 & & & & & & $\$$ \\
Number of employees & 30 & 63 & 78 & 6 & 27 & 78 \\
Revenues [in million \$] & 30 & $\$ 45.37$ & $\$ 148.50$ & $\$ 0.33$ & $\$ 5.02$ & $\$ 31.31$ \\
Total assets [in million \$] & 30 & $\$ 100.37$ & $\$ 241.10$ & $\$ 3.78$ & $\$ 13.25$ & $\$ 99.57$ \\
Market cap [in million \$] & 30 & $\$ 224.13$ & $\$ 510.21$ & $\$ 25.11$ & $\$ 37.72$ & $\$ 187.68$ \\
Portfolio returns & 239 & $0.01 \%$ & $1.96 \%$ & $-1.23 \%$ & $0.01 \%$ & $1.00 \%$ \\
\hline
\end{tabular}

This table displays the statistics of the equally weighted portfolio of all marijuana shares that are used for the event studies. Number of employees refers to the reported number of employees of the underlying firms at the time of the event. Note that for Event 1, a few firms did not report the exact number of employees. Revenues refer to the firms revenues in millions of USD that were disclosed in the financial report taken most closely to the event day. Total assets refer to the firms total assets in millions of USD that were disclosed in the financial report taken most closely to the event day. Market cap refers to the market capitalization of the underlying stocks in millions of USD one day prior to the event window, respectively. Portfolio returns refer to the daily returns over the samples' estimation periods

only a limited number of states allow recreational use (compare Fig. 1). The marijuana producers were underrepresented in our samples and in the stock market in general, most probably due to their limited bank access.

Table 1 reports the statistics for all events. The differences of the firms considered for the event studies are reflective of the strong growth of the marijuana industry between February 2014 and September 2019 (Marijuana Business Daily $^{\text {TM }}$ 2019). As a result, the findings offer insight into the marijuana industry at different stages. A typical (median) marijuana firm in our sample of the first (second/third) event has $7(10,27)$ employees, total assets of $\$ 1.52(\$ 3.70$, $\$ 13.25)$ million and annual revenues of $\$ 120,000(\$ 530,000, \$ 5,020,000)$. The market capitalization of the underlying stocks one day prior to the first (second/ third) event window ranges from $\$ 21.53$ (\$7.01, \$25.11) million at the 25th percentile to $\$ 176.99(\$ 22.85, \$ 187.68)$ million at the 75 th percentile with a median of $\$ 55.38$ (\$10.03, \$37.72) million. The portfolio returns of each sample are small but mostly positive and the distribution of returns becomes less dispersed for later events. 
The event study method closely follows Brown and Warner (1985). For the event study, we formed an equally weighted portfolio of the identified marijuana firms. We used the constant mean-return model and the market model to calculate the abnormal portfolio returns as well as the abnormal returns for all single stocks (MacKinlay 1997). We used different market benchmarks to mitigate any confounding effects of parallel market movements on the event day. We started with the constant mean-return model. Since the constant mean of the considered stocks is about zero percent (compare Table 1), we specified this as the zeroreturn model. Although the constant mean-return model is perhaps the simplest model, Brown and Warner (1985) find it often yields results similar to those of more sophisticated models. Furthermore, we used the one factor market model. Here, we estimated firm-specific model parameters with the S\&P 500 Index as well as the S\&P 600 Food, Beverage, \& Tobacco Index as alternative market benchmarks. We relied on different time frames preceding the three events. Due to the possibility that the issuing of the Guidance Fin-2014-G001 might have leaked into the market early, we started one trading day before the event in the earliest specification. For the court ruling, we based our main reasoning on the event day and the days afterwards because the judgment surprised the market. Due to the fact that the vote on the SAFE Banking Act was announced one trading day before the actual event, we started at minus one. All the event windows go up to 2 days after because most firms are traded infrequently so it might take more than a day before the information is reflected in the prices. Overall, the results appear robust for the different event windows with smaller variations. All results remain qualitatively unchanged with respect to the different market benchmarks. This indicates that our findings can be traced back to abnormal movements in the marijuana firms' stock prices.

\subsection{Survey design and sample}

To understand the perspective of marijuana SMEs and to identify how these firms cope with the lack of legal access to banking in their day-to-day business, we developed a survey. The survey was designed based on the well-established "Survey on the access to finance of SMEs" by the European Commission and the European Central Bank. The questions were adjusted and complemented to address challenges specific to the marijuana industry. The survey contains objective questions (e.g., "Does your company currently have a business account with an US American bank?"), that are complemented by subjective questions (e.g., "What in your opinion would be the biggest benefit of access to banking in regards to money transactions for your company?"). In addition, in order to limit bias stemming from socially desirable answers, we included questions that are constructed as "ideal experiments" (Hall 2008, p. 418). For example, to assess whether limited access to bank financing hinders firm growth we ask respondents for the first reaction in case of unexpected costs. The survey questions are provided in Appendix 2.

The paper-based survey was conducted directly by visiting dispensaries in the Denver area as well as at the 2017 National Cannabis Industry Association's 
(NCIA's) Seed-to-Sale Show. One of the authors personally distributed 70 surveys to qualified personnel, for example, store managers or owners, to be sent back via mail. Here we received ten responses. At the 2017 NCIA's Seed-to-Sale Show, one of the authors personally surveyed managers and owners of marijuana SMEs. In order to limit a potential sample bias stemming from a fear to disclose illegal activity by marijuana SMEs, complete anonymity was promised to any potential respondent. Four out of five respondents were willing to participate in the survey. ${ }^{2}$ In total, 58 marijuana SMEs participated in the survey. The survey sample includes very small firms (dispensaries) with direct customer contact as well as medium-sized firms that mainly supply other marijuana firms.

In the survey, most participants responded to all questions. Table 2 provides the summary statistics of the respondents and their firms. About $43 \%$ of the respondents were business owners of marijuana SMEs, followed by non-executive directors such as store managers $(\sim 40 \%)$ and executive directors $(\sim 17 \%)$. Most respondents had worked in the firm for over a year. Given their position as well as their working experience in the industry, our respondents should be very knowledgeable about the business activities and their firms' access to banking services. Regarding the geographic scope, our sample is heavily focused on Colorado (72\%) that is the oldest, most developed, and largest market for legal marijuana in the United States. Information from the remaining surveys indicates a similar, albeit less advanced, situation in other states. With around $45 \%$, nearly half of our sample consists of dispensaries with integrated growing facilities. The other 55\% of surveys come from SMEs that mainly do business with other marijuana firms.

About two-thirds of the marijuana sample firms have already broken even and consequently can rely on internal cash flow as a source of financing. Although $43 \%$ of our sample firms grew more than $50 \%$ in terms of turnover, their overall size remains small. Only $18 \%$ of the surveyed SMEs self-report revenues of more than $\$ 5$ million. ${ }^{3}$ Furthermore, the marijuana firms are on average young, because state licenses were only granted following legislation in 2010 for medical and after 2014 for recreational uses. Regarding the ownership structure, most marijuana SMEs are owned by a family or a single entrepreneur.

To better attribute our results to the marijuana firms' lack of access to banking and not to the overall characteristics of young SMEs, we conducted an online survey among US American microbreweries as a control. Using the results of the subjective questions it is possible to explain differences in behavior between the control group and the marijuana firms (Bertrand and Mullainathan 2001). In total 24 microbreweries participated. Apart from access to banking services, the microbreweries in our control sample closely resemble the surveyed marijuana SMEs with respect to age, size, and geographical location (see Table 2). Most of the respondents were business owners or executive managers from Colorado $(\sim 42 \%)$. About two-thirds of the surveyed microbreweries have less than ten employees, and none of them self-reports

\footnotetext{
2 Two additional responses were received by distributing the survey through an industry contact. Another two responses were received through follow-up calls via telephone.

3 Bhue (2018) reports similar revenues for marijuana firms in Washington State.
} 
Table 2 Summary statistics on respondents

\begin{tabular}{|c|c|c|c|c|}
\hline & \multirow{2}{*}{\multicolumn{2}{|c|}{$\frac{\text { Marijuana firms }}{[\mathrm{N}=58]}$}} & \multirow{2}{*}{\multicolumn{2}{|c|}{$\frac{\text { Microbreweries }}{[\mathrm{N}=24]}$}} \\
\hline & & & & \\
\hline & $\mathrm{N}$ & $\operatorname{In} \%$ & $\mathrm{~N}$ & $\operatorname{In} \%$ \\
\hline \multicolumn{5}{|l|}{ Position of respondent } \\
\hline Owner & 25 & 43 & 16 & 67 \\
\hline Executive director & 10 & 17 & 6 & 25 \\
\hline Non-executive director and other & 23 & 40 & 2 & 8 \\
\hline \multicolumn{5}{|l|}{ Working experience in the firm } \\
\hline Less than 1 year & 14 & 24 & 1 & 4 \\
\hline 1 year and more & 44 & 76 & 23 & 96 \\
\hline \multicolumn{5}{|l|}{ US state } \\
\hline Colorado & 42 & 72 & 10 & 42 \\
\hline California & 7 & 12 & 7 & 29 \\
\hline Other & 9 & 16 & 7 & 29 \\
\hline \multicolumn{5}{|l|}{ Industry sector } \\
\hline Dispensary with integrated grow & 26 & 45 & & \\
\hline Infused product maker & 12 & 21 & & \\
\hline Wholesale grower & 9 & 16 & & \\
\hline Ancillary technology & 6 & 10 & & \\
\hline Ancillary services & 5 & 8 & & \\
\hline \multicolumn{5}{|l|}{ Owners of firms } \\
\hline One owner & 30 & 52 & 5 & 21 \\
\hline Multiple people & 25 & 43 & 19 & 79 \\
\hline Venture capital enterprises & 2 & 3 & 0 & 0 \\
\hline Public shareholders & 1 & 2 & 0 & 0 \\
\hline \multicolumn{5}{|l|}{ Age of firms } \\
\hline Less than 2 years & 15 & 26 & 7 & 29 \\
\hline $2-4$ years & 17 & 29 & 7 & 29 \\
\hline $5-10$ years & 24 & 43 & 9 & 38 \\
\hline More than 10 years & 2 & 2 & 1 & 4 \\
\hline \multicolumn{5}{|l|}{ Firm size by employee } \\
\hline Micro firms & 26 & 45 & 16 & 67 \\
\hline Small firms & 23 & 40 & 7 & 29 \\
\hline Medium-sized firms & 9 & 15 & 1 & 4 \\
\hline \multicolumn{5}{|l|}{ Annual turnover } \\
\hline Up to $\$ 100,000$ & 16 & 30 & 3 & 13 \\
\hline Over $\$ 100,000$ and up to $\$ 1$ million & 16 & 30 & 15 & 65 \\
\hline Over $\$ 1$ million and up to $\$ 5$ million & 12 & 22 & 5 & 22 \\
\hline Over $\$ 5$ million & 10 & 18 & 0 & 0 \\
\hline \multicolumn{5}{|l|}{ Average growth rate in the last 2 years } \\
\hline Over $50 \%$ & 26 & 51 & 5 & 21 \\
\hline Between 20 and $50 \%$ & 14 & 27 & 7 & 29 \\
\hline Less than $20 \%$ & 8 & 16 & 5 & 21 \\
\hline
\end{tabular}


Table 2 (continued)

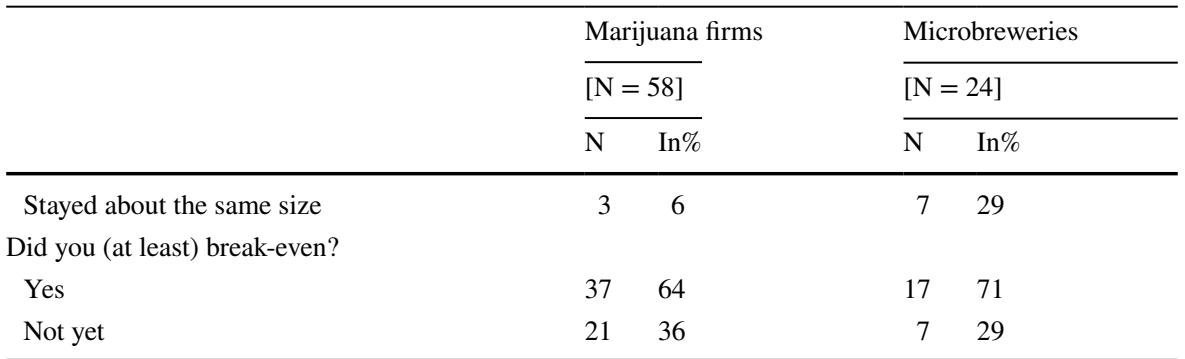

This table displays the summary statistics of the respondents and the marijuana firms/microbreweries the respondents work for. We report the respondents' position and their working experience in the firm. Additionally, we report the firm's characteristics such as location, industry sector, ownership structure, age, and size in terms of the number of employees, and annual turnover. Micro firms are firms with 1-9 employees, while small firms are those with 10-49 employees and medium-sized firms have 50-249 employees. We report the average growth rate over the last 2 years measured by turnover and whether the firms broke-even in the last year. We obtained 58 responses to our marijuana survey, but not all respondents provided information on the annual turnover and the average growth rate. We obtained 24 responses to our microbrewery survey, but not all respondents provided information on the annual turnover

revenues of more than $\$ 5$ million. Thus, the microbreweries in our sample are on average smaller than the marijuana SMEs. As a result of their smaller size and also of their slightly shorter history, the microbreweries should be on average more financially constrained. Similar to most marijuana SMEs, microbreweries are owned by a family or a single entrepreneur.

\section{Results}

\subsection{Event studies' results}

Table 3 reports the event study results for the Guidance Fin-2014-G001. Column 1 depicts the average abnormal returns (AARs) per trading day, i.e. the portfolio returns. The according two-sided t-statistics are displayed in column 2. Column 1 shows that the portfolio returns are positive and statistically significant on the event day and the day before. As the guidance was largely expected and involved many parties (see e.g., Altman 2014), some investors had already traded based on this information. With a positive AAR of around $4.4 \%$ on the event day, substantial perceived economic benefits from banking access is indicated. Apart from the portfolio returns, we also explore the individual securities to identify whether all firms are affected in a similar fashion or whether the aggregated results are only driven by a small number of marijuana firms. For the event day and the trading day before, we see that the vast majority of individual stocks show positive abnormal returns. When examining differences within the marijuana industry, positive abnormal returns on the event day were detected for all sectors except for consulting firms. This result is logical because the dominant role of consulting firms in the marijuana industry is to 
Table 3 Event 1: Guidance Fin-2014-G001

Panel A: zero-return benchmark

\begin{tabular}{|c|c|c|c|c|c|c|c|c|}
\hline & \multirow{2}{*}{$\begin{array}{l}\text { Average } \\
\text { abnormal } \\
\text { returns }\end{array}$} & \multirow[t]{2}{*}{ t-stats } & \multirow{2}{*}{$\begin{array}{l}\text { Positive/no } \\
\text { change/negative }\end{array}$} & \multicolumn{5}{|c|}{ Cumulative average abnormal returns } \\
\hline & & & & $(-1,2)$ & $(-1,1)$ & $(0,1)$ & $(0,2)$ & $(1,2)$ \\
\hline $\mathrm{t}-2$ & $1.86 \%$ & 0.81 & $15 / 2 / 11$ & & & & & \\
\hline $\mathrm{t}-1$ & $4.17 \%$ & $1.82 *$ & $18 / 2 / 8$ & $9.32 \%$ & $10.61 \%$ & $6.44 \%$ & $5.15 \%$ & $0.77 \%$ \\
\hline Event day & $4.38 \%$ & $1.91 *$ & $16 / 5 / 7$ & $2.03 * *$ & $2.67 * * *$ & $1.99 * *$ & 1.30 & 0.24 \\
\hline $\mathrm{t}+1$ & $2.06 \%$ & 0.90 & $14 / 2 / 12$ & & & & & \\
\hline $\mathrm{t}+2$ & $-1.29 \%$ & -0.56 & $9 / 1 / 18$ & & & & & \\
\hline
\end{tabular}

Panel B: market benchmark of S\&P 500 Index

\begin{tabular}{|c|c|c|c|c|c|c|c|c|}
\hline & \multirow{2}{*}{$\begin{array}{l}\text { Average } \\
\text { abnormal } \\
\text { returns }\end{array}$} & \multirow[t]{2}{*}{ t-stats } & \multirow[t]{2}{*}{ Positive/negative } & \multicolumn{5}{|c|}{ Cumulative average abnormal returns } \\
\hline & & & & $(-1,2)$ & $(-1,1)$ & $(0,1)$ & $(0,2)$ & $(1,2)$ \\
\hline$t-2$ & $0.91 \%$ & 0.40 & $13 / 15$ & & & & & \\
\hline $\mathrm{t}-1$ & $3.20 \%$ & 1.41 & $16 / 12$ & $5.47 \%$ & $7.71 \%$ & $4.51 \%$ & $2.27 \%$ & $-1.14 \%$ \\
\hline Event day & $3.41 \%$ & 1.50 & $14 / 14$ & 1.20 & $1.96^{*}$ & 1.40 & 0.58 & -0.35 \\
\hline$t+1$ & $1.10 \%$ & 0.48 & $14 / 14$ & & & & & \\
\hline $\mathrm{t}+2$ & $-2.24 \%$ & -0.98 & $7 / 21$ & & & & & \\
\hline
\end{tabular}

Panel C: market benchmark of S\&P 600 Food, Beverage, \& Tobacco Index

\begin{tabular}{|c|c|c|c|c|c|c|c|c|}
\hline & \multirow{2}{*}{$\begin{array}{l}\text { Average } \\
\text { abnormal } \\
\text { returns }\end{array}$} & \multirow[t]{2}{*}{ t-stats } & \multirow[t]{2}{*}{ Positive/negative } & \multicolumn{5}{|c|}{ Cumulative average abnormal returns } \\
\hline & & & & $(-1,2)$ & $(-1,1)$ & $(0,1)$ & $(0,2)$ & $(1,2)$ \\
\hline $\mathrm{t}-2$ & $0.92 \%$ & 0.40 & $13 / 15$ & & & & & \\
\hline$t-1$ & $3.46 \%$ & 1.52 & $16 / 12$ & $5.67 \%$ & $8.02 \%$ & $4.56 \%$ & $2.21 \%$ & $-1.23 \%$ \\
\hline Event day & $3.44 \%$ & 1.51 & $14 / 14$ & 1.25 & $2.04^{* * *}$ & 1.42 & 0.56 & -0.38 \\
\hline $\mathrm{t}+1$ & $1.12 \%$ & 0.49 & $14 / 14$ & & & & & \\
\hline$t+2$ & $-2.35 \%$ & -1.03 & $8 / 20$ & & & & & \\
\hline
\end{tabular}

This table displays the event study results for the Guidance Fin-2014-G001. The average abnormal returns (AARs) correspond to the excess returns with respect to three different benchmarks. In panel A, the AARs are calculated against the zero-return benchmark; panel B uses the S\&P 500 Index as a broad market benchmark; panel $\mathrm{C}$ relies on the SMEs in the food, beverage, and tobacco industries, by using the S\&P 600 Food, Beverage, and Tobacco Index as the market benchmark. Significance is calculated based on a two-sided $t$ test. Column 3 displays the number of individual marijuana firms that have abnormal positive (negative) returns on the specific trading day. The cumulative average abnormal returns are calculated based on five different event windows

The $* * *, * *$, and $*$ represent significance at the $1 \%, 5 \%$, and the $10 \%$ levels

broker private financing, for which attained access to banking could be perceived as negative.

In a second step, we accumulate the AARs over different event windows. The positive effect is especially strong for the event window of -1 to +1 , where we find a significant cumulative average abnormal return (CAAR) of around $10.6 \%$ for our marijuana stocks. In panels $\mathrm{B}$ and $\mathrm{C}$ of Table 3, the results are reported for the market benchmarks of the S\&P 500 Index and the S\&P 600 Food, Beverage, and 
Tobacco Index. For both benchmarks, we still find significant CAARs for the event window of -1 to +1 .

The event day is the same for all sample firms. To avoid bias in our results stemming from contemporaneous correlations among abnormal returns, we apply the standardized cross-sectional test by Kolari and Pynnönen (2010). The results remain qualitatively unchanged (compare Table 13 in Appendix 4.1). This also holds true when applying parametric and non-parametric tests (compare Tables 14, 15 in Appendix 4.1). During the considered time period, there were no other confounding events that affected the stock market in general, the marijuana industry or any individual member of the marijuana industry sample. This indicates that the abnormal returns stem from the perceived substantial economic benefits that banking access would provide. In addition, the results are significant in economic terms. For the event window of -1 to +1 , the average (median) marijuana stock increased its equity value by $\$ 19.6$ million ( $\$ 5.9$ million). Even after accounting for general market trends, these gains remain economically substantial for the firms and their shareholders. Applying the dividend discount model (DDM) for the event day yields an implied growth rate of about $9.9 \%$. To put this into context, we estimate the maximum sustainable growth rate according to Demirgüç-Kunt and Maksimovic (1998) as $9 \%$ for the marijuana industry portfolio. Thus, predicted legal access to banking services affects the marijuana industry's growth by about $0.9 \%$.

In Table 4, the event study results for the court ruling against the FCCU on January 5, 2016 are displayed. The portfolio returns around the event are positive on the days before the court ruling and the returns drop on the event day and turn negative. The significant positive AARs prior to the court ruling indicate the high hope for a positive court ruling and a fundamental change in the industry's access to banking. This hope was made clear in statements from industry representatives in the days before the court ruling. In contrast to the expectation of the industry, the FCCU's suit was rejected. Most marijuana stocks are traded on OTC markets at a low trading volume and frequency often resulting in delayed trading. In addition, the local (Coloradan) court ruling slowly reached the industry and investors. For example, even the directly related Credit Union National Association only reported the judgment three days afterwards (Credit Union National Association 2016). These are possible explanations for the negative average abnormal return detected 2 days after the court ruling. When examining differences within the marijuana industry, negative abnormal returns on the days following the court ruling are detected for all sectors except for consulting firms. In the case of the accumulated time frame 0 to +2 , we find a statistically significant negative CAAR of about $-7.9 \%$ resulting from the rejection of the FCCU's suit. In other words, the court ruling led to a value decline of about $\$ 9.7$ million ( $\$ 0.8$ million) for the average (median) member of the marijuana industry. Although the second event has a less significant effect than the first event, the overall economic impact to the industry remains strong. Applying the DDM for the event day yields an implied growth rate of about $10.2 \%$. In comparison, the estimated maximum growth rate is $11.3 \%$. Thus, the perceived setback to gaining legal banking access reduced growth by about $1.1 \%$. Panel B of Table 4 displays the results for the market model where the S\&P 500 Index serves as the benchmark. Panel C of Table 4 gives the results for the S\&P 600 Food, Beverage, \& Tobacco Index. Similar 
Table 4 Event 2: the Fourth Corner Credit Union case

Panel A: zero-return benchmark

\begin{tabular}{lccllllll}
\hline & $\begin{array}{l}\text { Average } \\
\text { abnormal } \\
\text { returns }\end{array}$ & t-stats & & $\begin{array}{l}\text { Positive/ } \\
\text { no change/ } \\
\text { negative }\end{array}$ & & \multicolumn{5}{l}{ Cumulative average abnormal returns } & \\
\cline { 5 - 8 } & & & $(-1,2)$ & $(-1,1)$ & $(0,1)$ & $(0,2)$ & $(1,2)$ \\
$\mathrm{t}-2$ & $3.44 \%$ & $1.98^{* *}$ & $13 / 6 / 9$ & & & & & \\
$\mathrm{t}-1$ & $3.09 \%$ & $1.78^{*}$ & $9 / 6 / 13$ & $-4.76 \%$ & $-0.92 \%$ & $-4.01 \%$ & $-7.85 \%$ & $-5.15 \%$ \\
Event day & $-2.70 \%$ & -1.56 & $11 / 4 / 13$ & -1.37 & -0.31 & -1.63 & $-2.61^{* * *}$ & $-2.10^{* *}$ \\
$\mathrm{t}+1$ & $-1.31 \%$ & -0.76 & $6 / 6 / 16$ & & & & & \\
$\mathrm{t}+2$ & $-3.84 \%$ & $-2.21^{* *}$ & $7 / 5 / 16$ & & & & & \\
\hline
\end{tabular}

Panel B: market benchmark of S\&P 500 Index

\begin{tabular}{|c|c|c|c|c|c|c|c|c|}
\hline & \multirow{2}{*}{$\begin{array}{l}\text { Average } \\
\text { abnormal } \\
\text { returns }\end{array}$} & \multirow[t]{2}{*}{ t-stats } & \multirow{2}{*}{$\begin{array}{l}\text { Positive/ } \\
\text { negative }\end{array}$} & \multicolumn{5}{|c|}{ Cumulative average abnormal returns } \\
\hline & & & & $(-1,2)$ & $(-1,1)$ & $(0,1)$ & $(0,2)$ & $(1,2)$ \\
\hline $\mathrm{t}-2$ & $3.71 \%$ & $2.14 * *$ & $14 / 14$ & & & & & \\
\hline $\mathrm{t}-1$ & $3.45 \%$ & $1.99 * *$ & $11 / 17$ & $-3.50 \%$ & $-0.14 \%$ & $-3.59 \%$ & $-6.95 \%$ & $-4.35 \%$ \\
\hline Event day & $-2.60 \%$ & -1.50 & $14 / 14$ & -1.00 & -0.05 & -1.47 & $-2.31 * *$ & $-1.77 *$ \\
\hline$t+1$ & $-0.99 \%$ & -0.57 & $11 / 17$ & & & & & \\
\hline $\mathrm{t}+2$ & $-3.36 \%$ & $-1.93 *$ & $12 / 16$ & & & & & \\
\hline
\end{tabular}

Panel C: market benchmark of S\&P 600 Food, Beverage, \& Tobacco Index

\begin{tabular}{|c|c|c|c|c|c|c|c|c|}
\hline & \multirow{2}{*}{$\begin{array}{l}\text { Average } \\
\text { abnormal } \\
\text { returns }\end{array}$} & \multirow[t]{2}{*}{ t-stats } & \multirow{2}{*}{$\begin{array}{l}\text { Positive/ } \\
\text { negative }\end{array}$} & \multicolumn{5}{|c|}{ Cumulative average abnormal returns } \\
\hline & & & & $(-1,2)$ & $(-1,1)$ & $(0,1)$ & $(0,2)$ & $(1,2)$ \\
\hline $\mathrm{t}-2$ & $3.60 \%$ & $2.08 * *$ & $16 / 12$ & & & & & \\
\hline $\mathrm{t}-1$ & $3.50 \%$ & $2.02 * *$ & $11 / 17$ & $-3.78 \%$ & $-0.17 \%$ & $-3.67 \%$ & $-7.28 \%$ & $-4.80 \%$ \\
\hline Event day & $-2.48 \%$ & -1.43 & $12 / 16$ & -1.09 & -0.06 & -1.50 & $-2.43 * *$ & $-1.96^{* *}$ \\
\hline $\mathrm{t}+1$ & $-1.19 \%$ & -0.69 & $12 / 16$ & & & & & \\
\hline$t+2$ & $-3.61 \%$ & $-2.08 * *$ & $8 / 20$ & & & & & \\
\hline
\end{tabular}

This table displays the event study results around the court ruling against the Fourth Corner Credit Union. The average abnormal returns (AARs) correspond to the excess returns with respect to three different benchmarks. In panel A, the AARs are calculated against the zero-return benchmark; panel B uses the S\&P 500 Index as a broad market benchmark; panel C relies on the SMEs in the food, beverage, and tobacco industries, by using the S\&P 600 Food, Beverage, and Tobacco Index as the market benchmark. Significance is calculated based on a two-sided t test. Column 3 displays the number of individual marijuana firms that have abnormal positive (negative) returns on the specific trading day. The cumulative average abnormal returns are calculated based on five different event windows

The $* * *, * *$, and $*$ represent significance at the $1 \%, 5 \%$, and the $10 \%$ levels

to our baseline case, we find significant cumulative average abnormal returns for the event window of 0 to +2 resulting from the legally denied access to banking. Again, our results remain qualitatively unchanged when applying parametric and non-parametric tests (compare Tables 16, 17, 18 in Appendix 4.2). Upon examination for confounding events, it was identified that the US stock market in general was affected by turbulence in the Chinese stock market. In addition, there were concerns about the Chinese economy that led to a strong decline of mainly export-oriented firms in 
the S\&P 500 Index during the event window. ${ }^{4}$ Since the US marijuana industry does not export to China, this event should not significantly affect the marijuana stocks. In order to confirm that spillover effects on marijuana stocks from our sample listed in the NYSE and NASDAQ were not the sole drivers of the negative returns, we reaffirm our results with a portfolio solely consisting OTC market stocks. In conclusion, our results can largely be traced back to the continued denied access to banking.

Table 5 illustrates the event study results for the US House of Representatives voting on the SAFE Banking Act in 2019. Column 1 shows positive portfolio returns on the day of the voting and negative returns on the days before and afterwards. The unclear pattern of the returns imminently around the vote appears rather surprising. It can, however, be understood by considering the news coverage of the vote. One day prior to the scheduled vote, there were rumors that the vote for the bill could be delayed. In addition, the vote was scheduled "under suspension of the rules", i.e. as a take it or leave it proposition that must be approved by a two-thirds majority in the House, making a success seem less likely. In the end, however the vote on the SAFE Banking Act took place and was passed with an overwhelming majority. In addition to the Democrats, surprisingly nearly half of the Republican caucus voted for the bill. The initial euphoria of the marijuana industry was subdued by the likely failure of the bill in the Senate (a positive vote in the House of Representatives and the Senate is necessary to pass a bill into a law). Moreover, while the SAFE Banking Act improves the status quo, it does not ensure financial services to the marijuana industry. This led to a significant negative portfolio return of $-5.92 \%$ in the cumulative event window of +1 to +2 . In panels B and C of Table 5, the results are reported for the market benchmarks of the S\&P 500 Index and the S\&P 600 Food, Beverage, and Tobacco index. For both benchmarks, we still find significant negative CAARs for the event window of +1 to +2 . Again, our results remain qualitatively unchanged if we apply parametric and non-parametric tests (compare Tables 19, 20 and 21 in Appendix 4.3). The results are also significant in economic terms. For the event window of +1 to +2 the average (median) value of marijuana firms declined by about $\$ 13.3$ million ( $\$ 2.2$ million). Applying the DDM for the event day yields an implied growth rate of about $10.6 \%$. In comparison, the estimated maximum growth rate is $14.5 \%$. Thus, the reiterated legally denied access to banking services lowers the marijuana industry's growth by about 3.9\%. To ensure that our results can be traced back to the denied access to banking services, we again searched for confounding events. While the marijuana industry in general was only affected by this vote, three firms of our sample were also affected by firm-specific announcements. In particular, Kushco Holdings announced a secondary offering 1 day after the voting that negatively affected its stock. In contrast, CBDMD and United Cannabis both announced new partnerships on the event day and the day afterward, respectively. Still, the main results remain qualitatively unchanged even if we exclude these three firms.

In summary, the event studies' results show that the marijuana industry perceives legal access to banking as crucial. More information about how typical marijuana firms, i.e. SMEs, cope with the restricted access to banking will be attained from the survey presented in the following section.

\footnotetext{
${ }^{4}$ For more information, see Koptis (2016) and NBC NEWS (2016).
} 
Table 5 Event 3: the SAFE Banking Act

Panel A: zero-return benchmark

\begin{tabular}{lllllllll}
\hline & $\begin{array}{l}\text { Average } \\
\text { abnormal } \\
\text { returns }\end{array}$ & t-stats & $\begin{array}{l}\text { Positive/ } \\
\text { no change/ } \\
\text { negative }\end{array}$ & & \multicolumn{6}{l}{ Cumulative average abnormal returns } & \\
\cline { 6 - 8 } & & & $(-1,2)$ & $(-1,1)$ & $(0,1)$ & $(0,2)$ & $(1,2)$ \\
\hline $\mathrm{t}-2$ & $0.28 \%$ & 0.19 & $9 / 3 / 18$ & & & & & \\
$\mathrm{t}-1$ & $-2.64 \%$ & $-1.80^{*}$ & $4 / 4 / 22$ & $-6.26 \%$ & $-3.34 \%$ & $-0.70 \%$ & $-3.62 \%$ & $-5.92 \%$ \\
Event day & $2.30 \%$ & 1.57 & $12 / 6 / 12$ & $-2.14 * *$ & -1.32 & -0.34 & -1.43 & $-2.87 * * *$ \\
$\mathrm{t}+1$ & $-3.00 \%$ & $-2.05^{* *}$ & $5 / 6 / 19$ & & & & & \\
$\mathrm{t}+2$ & $-2.92 \%$ & $-2.00^{* * *}$ & $6 / 6 / 18$ & & & & & \\
\hline
\end{tabular}

Panel B: narket benchmark of S\&P 500 Index

\begin{tabular}{|c|c|c|c|c|c|c|c|c|}
\hline & \multirow{2}{*}{$\begin{array}{l}\text { Average } \\
\text { abnormal } \\
\text { returns }\end{array}$} & \multirow[t]{2}{*}{ t-stats } & \multirow{2}{*}{$\begin{array}{l}\text { Positive/ } \\
\text { negative }\end{array}$} & \multicolumn{5}{|c|}{ Cumulative average abnormal returns } \\
\hline & & & & $(-1,2)$ & $(-1,1)$ & $(0,1)$ & $(0,2)$ & $(1,2)$ \\
\hline $\mathrm{t}-2$ & $0.30 \%$ & 0.21 & $9 / 21$ & & & & & \\
\hline $\mathrm{t}-1$ & $-2.05 \%$ & -1.41 & $8 / 22$ & $-5.56 \%$ & $-3.00 \%$ & $-0.95 \%$ & $-3.51 \%$ & $-5.39 \%$ \\
\hline Event day & $1.88 \%$ & 1.30 & $13 / 17$ & $-1.91 *$ & -1.19 & -0.46 & -1.39 & $-2.62 * * *$ \\
\hline$t+1$ & $-2.83 \%$ & $-1.95^{*}$ & $7 / 23$ & & & & & \\
\hline $\mathrm{t}+2$ & $-2.56 \%$ & $-1.76^{*}$ & $9 / 21$ & & & & & \\
\hline
\end{tabular}

Panel C: market benchmark of S\&P 600 Food, Beverage, \& Tobacco Index

\begin{tabular}{|c|c|c|c|c|c|c|c|c|}
\hline & \multirow{2}{*}{$\begin{array}{l}\text { Average } \\
\text { abnormal } \\
\text { returns }\end{array}$} & \multirow[t]{2}{*}{ t-stats } & \multirow{2}{*}{$\begin{array}{l}\text { Positive/ } \\
\text { negative }\end{array}$} & \multicolumn{5}{|c|}{ Cumulative average abnormal returns } \\
\hline & & & & $(-1,2)$ & $(-1,1)$ & $(0,1)$ & $(0,2)$ & $(1,2)$ \\
\hline $\mathrm{t}-2$ & $0.20 \%$ & 0.13 & $9 / 21$ & & & & & \\
\hline $\mathrm{t}-1$ & $-2.48 \%$ & $-1.70^{*}$ & $6 / 24$ & $-6.16 \%$ & $-3.45 \%$ & $-0.97 \%$ & $-3.68 \%$ & $-5.66 \%$ \\
\hline Event day & $1.98 \%$ & 1.36 & $14 / 16$ & $-2.11 * *$ & -1.37 & -0.47 & -1.46 & $-2.75 * * *$ \\
\hline$t+1$ & $-2.95 \%$ & $-2.02 * *$ & $7 / 23$ & & & & & \\
\hline$t+2$ & $-2.71 \%$ & $-1.86^{*}$ & $8 / 22$ & & & & & \\
\hline
\end{tabular}

This table displays the event study results around the voting by the US House of Representatives on the SAFE Banking Act. The average abnormal returns (AARs) correspond to the excess returns with respect to three different benchmarks. In panel A, the AARs are calculated against the zero-return benchmark; panel B uses the S\&P 500 Index as a broad market benchmark; panel C relies on the SMEs in the food, beverage, and tobacco industries, by using the S\&P 600 Food, Beverage, \& Tobacco Index as the market benchmark. Significance is calculated based on a two-sided t test. Column 3 displays the number of individual marijuana firms that have abnormal positive (negative) returns on the specific trading day. The cumulative average abnormal returns are calculated based on five different event windows

The $* * *, * *$, and $*$ represent significance at the $1 \%, 5 \%$, and the $10 \%$ levels

\subsection{Survey results}

\subsubsection{Financial transaction management}

Financial transaction and payment services are one of the most prominent economic functions of banks. Levine (1997) refers to them as "easing the exchange of goods and services." Financial transaction and payment services refer to the exchange of goods 
Table 6 Financial transaction management

Panel A: Handling of financial transactions

\begin{tabular}{|c|c|c|c|c|}
\hline & \multicolumn{2}{|c|}{ Marijuana firms } & \multicolumn{2}{|c|}{ Microbreweries } \\
\hline & \multicolumn{2}{|c|}{$\left[\mathrm{N}=45^{\mathrm{a}}\right]$} & \multicolumn{2}{|c|}{$[\mathrm{N}=24]$} \\
\hline & $\mathrm{N}$ & $\operatorname{In} \%$ & $\mathrm{~N}$ & $\mathrm{In} \%$ \\
\hline \multicolumn{5}{|c|}{ How do You Receive Most of Your Revenue? } \\
\hline Cash & 31 & 70 & 1 & 4 \\
\hline Check & 13 & 30 & 4 & 17 \\
\hline Via a bank & 3 & 7 & 19 & 79 \\
\hline Via a non-bank (e.g., Bitcoin) & 0 & 0 & 0 & 0 \\
\hline \multicolumn{5}{|l|}{ How do you pay most of your bills? } \\
\hline Check & 18 & 40 & 9 & 38 \\
\hline Cash & 16 & 36 & 0 & 0 \\
\hline Via a bank & 15 & 33 & 15 & 63 \\
\hline Via a non-bank (e.g., Bitcoin) & 0 & 0 & 0 & 0 \\
\hline
\end{tabular}

Panel B: Access to banking of marijuana firms

\begin{tabular}{ll} 
Marijuana firms \\
\hline$[\mathrm{N}=56]$ \\
\hline $\mathrm{N} \quad$ In $\%$
\end{tabular}

Does your firm currently have a bank account?

$\begin{array}{lll}\text { Yes, directly } & 30 & 54 \\ \text { Yes, indirectly (e.g., private account) } & 12 & 2 \\ \text { No } & 14 & 25\end{array}$

Perceived stability of bank relationship

$\begin{array}{lll}\text { Long-term } & 25 & 64 \\ \text { Short-term } & 10 & 26 \\ \text { Terminable } & 4 & 10\end{array}$

Did the bank reject or close your account?

$\begin{array}{lll}\text { Yes } & 31 & 55 \\ \text { No } & 25 & 45\end{array}$

Panel A of this table displays the responses on the handling of money transactions by marijuana firms and microbreweries. We report how firms receive revenues and pay their bills. In panel B, we report how many marijuana firms currently have bank accounts and how often bank accounts were closed as well as their perceived stability of the banking relationship. Note that for some questions we received multiple answers

${ }^{a}$ Multiple answers possible

and services with the firms' customers, suppliers, investors, and with the tax authorities. Panel A of Table 6 provides evidence on how the surveyed marijuana SMEs and microbreweries handle their transactions with customers, suppliers, and other parties. 
It is shown that marijuana SMEs handle most of their transactions with either cash or checks. ${ }^{5}$ More than two-thirds report cash as their main source of revenue from customers and clients followed by checks (approximately one-third). Bankbased transactions do not play a major role in the revenues of most marijuana SMEs. Considering how they pay their suppliers, investors, and similar parties, all three forms of transactions are important. Checks, however, are most commonly used. Surprisingly, no firm listed alternative payment services like Bitcoins as their major transaction platform. In comparison, firms that do have access to banking, i.e. microbreweries, heavily rely on bank-based transactions. $79 \%$ of the microbreweries report bank-based transactions as their major source of revenues and none pay their bills in cash.

Although most marijuana firms rely predominantly on cash for transactions, over half of the surveyed firms have a bank account. This result is surprising as banks usually reject a client or terminate the business relations as soon as they become aware of the marijuana business activity. Although 12 SMEs indicate that they circumvented the rules by operating at least some transactions via their private or a third-party bank account, thirty SMEs report that they managed to open a corporate bank account. To the subjective question about whether they believe to have a long-term relationship $64 \%$ answered "yes". Based on additional comments by the respondents (e.g., "I hope that this time it is a long-term relationship"), this result is more an indication for the desire to have a stable banking relationship and less indicative of the current situation.

Still, and as indicated by the previous responses, these bank accounts are not used by most marijuana SMEs to handle their main payment transactions. One reason maybe out of fear that the bank discovers their status as marijuana firms and freezes or terminates their accounts. This threat also prevents marijuana SMEs from establishing a closer bank-client relationship that could overcome information asymmetries (Kysucky and Norden 2015). When directly asked, more than 50\% of the respondents indicate that, due to their status as a marijuana firm, they had been rejected by a bank or their existing bank account had been terminated.

When asked for the most important and strongest benefit of having a regular bank account to handle transactions, most respondents name a reduction in risk (see Table 7). With an average score of 4.43 out of five, more than $80 \%$ expect that having a bank account would significantly reduce the risk of day-to-day business operations. With a regular transaction account, these firms would face a lower risk of being robbed, of misappropriation by employees, and of crimes related to money laundering. This is in line with anecdotal evidence. To pay his taxes Jerred Kiloh from United Cannabis Business Alliance, for example "ha[s] to use a six-story parking structure 500 yards from the [local] office of finance and walk through a homeless encampment with a duffel bag full of cash" [as cited in Chiang (2017, p. 13)].

\footnotetext{
5 Note that there are several forms of checks, e.g., cashier's check, that do not require a bank account (compare e.g., Stavins 2018 for an overview of the different payment instruments in the United States). The check can be cashed in at regular cash or retail stores. These non-bank money services are also subject to federal law and will not knowingly accept money from marijuana-related firms. However, if cash amounts are small, few questions are asked.
} 
Table 7 Benefits of access to electronic payment services via banks

\begin{tabular}{|c|c|c|c|c|c|c|}
\hline Row & Benefits & Mean score & $\begin{array}{l}\% \text { with } 4 \\
\text { or } 5 \text { score }\end{array}$ & $\mathrm{N}$ & $\begin{array}{l}\text { Significant differences } \\
\text { in mean score vs. rows }\end{array}$ & $\begin{array}{l}\text { H0: mean } \\
\text { score }=3\end{array}$ \\
\hline (1) & Reduced risks & 4.43 & 83 & 46 & $2-5$ & $* * *$ \\
\hline (2) & Reduced time & 3.83 & 63 & 46 & 1,5 & $* * *$ \\
\hline (3) & More satisfied customers & 3.83 & 67 & 46 & 1,5 & $* * *$ \\
\hline (4) & Reduced costs & 3.74 & 63 & 46 & 1,5 & $* * *$ \\
\hline (5) & More satisfied suppliers & 3.22 & 48 & 46 & $1-4$ & \\
\hline
\end{tabular}

This table reports the survey responses on the benefits of access to electronic payment services offered by banks. Respondents were asked to indicate the level of importance on a scale of 1 (not at all beneficial) to 5 (very beneficial). Column 3 reports the mean score where higher values correspond to larger benefits. Column 4 presents the percent of respondents who indicated the beneficial levels of 4 or 5 (somewhat beneficial and very beneficial). Column 5 displays the number of respondents. Column 6 reports the result of a t test of the null hypothesis that the mean score for a given benefit is equal to the mean score for each of the other benefits, where only significant differences at the $5 \%$ level are reported. Column 7 reports the $t$ test of the null hypothesis that each mean score is equal to three (neither beneficial nor not beneficial)

The $* * *$ indicate statistical significance at the $1 \%$ level

In addition to the reduction in risk, respondents state that a bank account would increase their operating efficiency by reducing time and costs, as well as improving customer satisfaction. The extra resources spent on counting money and handling transactions could be used to get additional funding. Currently, it is very labor and time intensive to ensure that each transaction is made correctly and on time. With an average of around 3.8 out of 5 , the three effects are perceived as equally important, although the average is significantly lower than that of risk reduction. The lack of access to the bank transaction services appears to not be relevant for the suppliers' satisfaction.

Overall, Tables 6 and 7 indicate the challenges of marijuana SMEs in handling financial transactions. The lack of legal access to banks makes these firms operate with cash and checks. These options cause a threat to the firms' security and reduce their operating efficiency, thereby hampering growth. Without widespread access to payment services, credit repayments to non-banks are also subject to theft, which decreases the creditworthiness of the firms.

\subsubsection{Bank loans and credit lines}

A second banking service that is typically crucial for SMEs is lending (see, e.g., Berger and Udell 1998; Robb and Robinson 2014). Bank lending includes standard loans and short-term liquidity facilities, such as overdrafts or credit lines. Unlike larger established firms, young SMEs lack access to public institutional debt and capital markets. The fluctuations in SMEs' profits make free cash flow a less stable source of financing, making them more dependent on bank loans (Beck et al. 2008). However, irrespective of the size, firms rely heavily on bank credit lines or overdraft facilities to handle temporary fluctuations in the firms' cash flows. Figure 2 shows how marijuana SMEs cope with the lack of access to bank lending for their current and future business activities. 


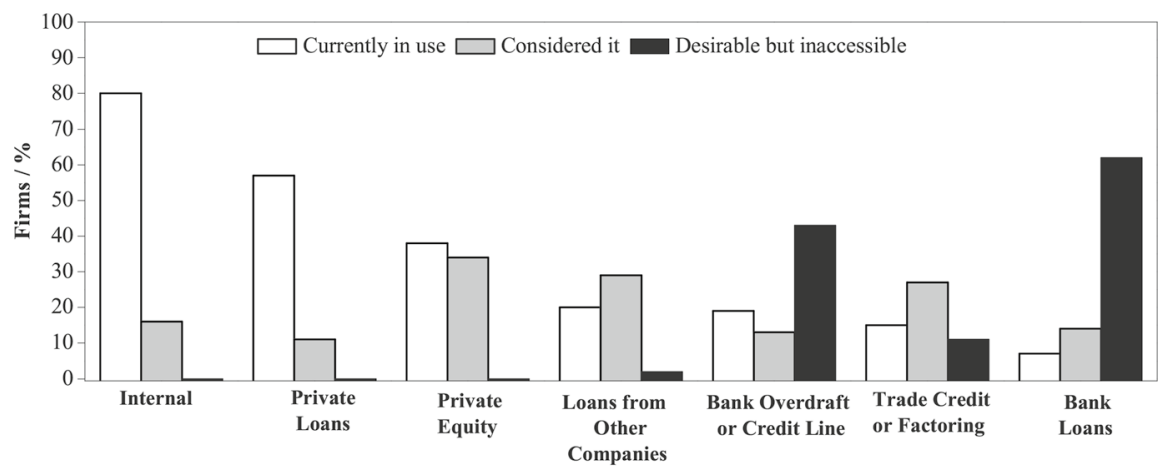

Fig. 2 Financing sources of marijuana SMEs

Figure 2 and panel A of Table 8 show that most marijuana SMEs rely on internal funding as their major source of financing. Whenever available in a sufficient quantity, internal funding is usually an easy way of financing new and profitable operations. Most surveyed SMEs state that internal funds were available at least to some degree. However, firms that heavily rely on internal cash flow to finance investments tend to systematically underinvest and are classified as financially constrained (Almeida et al. 2004; Almeida and Campello 2007). This in turn holds back firm and ultimately economic growth (Beck et al. 2005; Ayyagari et al. 2008).

Figure 2 also shows that most marijuana SMEs finance their operations with private loans from friends, family members, wealthy private individuals, and private equity. Although private loans and private equity can have desirable features, they are usually more costly than traditional bank loans. According to Marijuana Business Daily ${ }^{\mathrm{TM}}$ (2016), these private loans are available for an average interest rate of $11 \%$. In comparison, the US Small Business Administration offers financing to SMEs not served by traditional banks and (only) charges between $5.75 \%$ and $8.25 \%$. The more sophisticated financing instruments, such as factoring or trade credit, appear to be irrelevant for most marijuana SMEs.

Bank lending is not a major financing source for marijuana SMEs. Less than $20 \%$ have access to bank overdrafts or credit lines and less than $10 \%$ rely on bank loans, most likely via their private accounts. About 68\% (43\%) state that bank loans (overdraft facilities) are desirable but inaccessible (see panel A of Table 8). The lack of bank funding is most probably the result of the legal situation. When directly asked, about $46 \%$ admit that bank loans are their most preferred source of new funding.

The surveyed microbreweries also heavily rely on internal funds and private loans. In comparison, however, bank loans are their third major financing source. $42 \%$ of the surveyed microbreweries state that they currently use bank loans and another 33\% considers to apply for one (compare panel B of Table 8). Furthermore, about $38 \%$ currently use bank overdrafts or credit lines to finance their business.

Overall, the results in Table 8 show that marijuana SMEs lack access to bank lending but would prefer bank loans, credit lines and overdraft facilities to finance their future operations. The marijuana firms' inability to access bank lending causes 
Table 8 Bank loans and credit lines

Panel A: financing sources of marijuana firms

\begin{tabular}{|c|c|c|c|c|c|c|c|c|}
\hline \multirow[t]{2}{*}{ Financing sources } & \multicolumn{2}{|c|}{$\begin{array}{l}\text { Currently or previously } \\
\text { in use }\end{array}$} & \multicolumn{2}{|c|}{$\begin{array}{l}\text { Considered it for } \\
\text { the future }\end{array}$} & \multicolumn{2}{|c|}{$\begin{array}{l}\text { Desirable, but } \\
\text { inaccessible }\end{array}$} & \multicolumn{2}{|c|}{ Not relevant } \\
\hline & $\mathrm{N}$ & $\operatorname{In} \%$ & $\mathrm{~N}$ & $\operatorname{In} \%$ & $\mathrm{~N}$ & $\operatorname{In} \%$ & $\mathrm{~N}$ & $\operatorname{In} \%$ \\
\hline Internal funds $(\mathrm{N}=56)$ & 45 & 80 & 9 & 16 & 0 & 0 & 2 & 4 \\
\hline Private loans $(\mathrm{N}=56)$ & 32 & 57 & 6 & 11 & 0 & 0 & 18 & 32 \\
\hline Private equity $(\mathrm{N}=56)$ & 21 & 38 & 19 & 34 & 0 & 0 & 16 & 29 \\
\hline $\begin{array}{l}\text { Loans from other firms } \\
\qquad(\mathrm{N}=55)\end{array}$ & 11 & 20 & 16 & 29 & 1 & 2 & 27 & 49 \\
\hline $\begin{array}{l}\text { Bank overdraft or credit } \\
\text { line }(\mathrm{N}=54)\end{array}$ & 10 & 19 & 7 & 13 & 23 & 43 & 14 & 26 \\
\hline $\begin{array}{l}\text { Trade credit or factoring } \\
\qquad(\mathrm{N}=55)\end{array}$ & 8 & 15 & 15 & 27 & 6 & 11 & 26 & 47 \\
\hline Bank loans $(\mathrm{N}=56)$ & 4 & 7 & 8 & 14 & 38 & 68 & 6 & 11 \\
\hline Issuing debt $(\mathrm{N}=55)$ & 2 & 4 & 6 & 11 & 6 & 11 & 41 & 75 \\
\hline Public equity $(\mathrm{N}=56)$ & 1 & 2 & 17 & 30 & 5 & 9 & 33 & 59 \\
\hline \multicolumn{3}{|c|}{ Most preferred external financing source $[\mathrm{N}=56]$} & $\mathrm{N}$ & & \multicolumn{2}{|c|}{$\operatorname{In} \%$} & & \\
\hline \multicolumn{3}{|l|}{ Bank loans } & 26 & & \multicolumn{2}{|c|}{46} & & \\
\hline \multicolumn{3}{|c|}{ Equity capital (private or public) } & 16 & & \multicolumn{2}{|c|}{29} & & \\
\hline \multicolumn{3}{|l|}{ Loans from other sources } & 8 & & \multicolumn{2}{|c|}{14} & & \\
\hline \multicolumn{2}{|l|}{ None } & & 6 & & \multicolumn{2}{|c|}{11} & & \\
\hline
\end{tabular}

Panel B: financing sources of microbreweries

\begin{tabular}{|c|c|c|c|c|c|c|c|c|}
\hline \multirow[t]{2}{*}{ Financing sources } & \multicolumn{2}{|c|}{$\begin{array}{l}\text { Currently or previ- } \\
\text { ously in use }\end{array}$} & \multicolumn{2}{|c|}{$\begin{array}{l}\text { Considered it for } \\
\text { the future }\end{array}$} & \multicolumn{2}{|c|}{$\begin{array}{l}\text { Desirable, but } \\
\text { inaccessible }\end{array}$} & \multicolumn{2}{|c|}{ Not relevant } \\
\hline & $\mathrm{N}$ & $\operatorname{In} \%$ & $\mathrm{~N}$ & $\operatorname{In} \%$ & $\mathrm{~N}$ & $\operatorname{In} \%$ & $\mathrm{~N}$ & $\operatorname{In} \%$ \\
\hline Private loans $(\mathrm{N}=24)$ & 16 & 67 & 1 & 4 & 1 & 4 & 6 & 25 \\
\hline Internal funds $(\mathrm{N}=24)$ & 13 & 54 & 4 & 17 & 1 & 4 & 6 & 25 \\
\hline Bank loans $(\mathrm{N}=24)$ & 10 & 42 & 8 & 33 & 2 & 8 & 4 & 17 \\
\hline $\begin{array}{l}\text { Bank overdraft or credit } \\
\text { line }(\mathrm{N}=24)\end{array}$ & 9 & 38 & 6 & 25 & 0 & 0 & 9 & 38 \\
\hline $\begin{array}{l}\text { Trade credit or factoring } \\
(\mathrm{N}=24)\end{array}$ & 4 & 17 & 4 & 17 & 1 & 4 & 15 & 63 \\
\hline Private equity $(\mathrm{N}=24)$ & 3 & 13 & 8 & 33 & 0 & 0 & 13 & 54 \\
\hline $\begin{array}{l}\text { Loans from other firms } \\
\qquad(\mathrm{N}=24)\end{array}$ & 2 & 8 & 4 & 17 & 0 & 0 & 18 & 75 \\
\hline Public equity $(\mathrm{N}=24)$ & 1 & 4 & 2 & 8 & 3 & 13 & 18 & 75 \\
\hline Issuing debt $(\mathrm{N}=24)$ & 0 & 0 & 2 & 8 & 2 & 8 & 20 & 83 \\
\hline
\end{tabular}


Table 8 (continued)

Panel C: financial constraints of marijuana firms and microbreweries

\begin{tabular}{|c|c|c|c|c|}
\hline \multirow{2}{*}{$\begin{array}{l}\text { Reaction in case of } \\
\text { unexpected costs }\end{array}$} & \multicolumn{2}{|c|}{ Marijuana firms } & \multicolumn{2}{|c|}{ Microbreweries } \\
\hline & $\mathrm{N}=56$ & $\operatorname{In} \%$ & $\mathrm{~N}=24$ & $\operatorname{In} \%$ \\
\hline Raising capital & 32 & 57 & 18 & 75 \\
\hline $\begin{array}{l}\text { Cut back invest- } \\
\text { ments }\end{array}$ & 12 & 21 & 3 & 13 \\
\hline $\begin{array}{l}\text { Delay payments of } \\
\text { suppliers }\end{array}$ & 6 & 11 & 2 & 8 \\
\hline Lay off employees & 3 & 5 & 0 & 0 \\
\hline $\begin{array}{l}\text { Increase the price } \\
\text { of products }\end{array}$ & 2 & 4 & 0 & 0 \\
\hline \multirow[t]{3}{*}{$\begin{array}{l}\text { Delay wage pay- } \\
\text { ments }\end{array}$} & 1 & 2 & 1 & 4 \\
\hline & \multicolumn{2}{|c|}{ Marijuana firms } & \multicolumn{2}{|c|}{ Microbreweries } \\
\hline & \multicolumn{2}{|l|}{$[\mathrm{N}=58]$} & \multicolumn{2}{|c|}{$[\mathrm{N}=24]$} \\
\hline $\begin{array}{l}\text { Restricting growth } \\
\text { opportunities }\end{array}$ & $\mathrm{N}$ & $\operatorname{In} \%$ & $\mathrm{~N}$ & $\operatorname{In} \%$ \\
\hline Yes & 40 & 69 & 6 & 25 \\
\hline No & 18 & 31 & 18 & 75 \\
\hline
\end{tabular}

This table reports the survey responses related to the financing of marijuana firms and microbreweries. Panels A and B display several financing sources that are used, considered, or desired by the firms. Panel $\mathrm{C}$ shows the first reaction in case of unexpected costs for marijuana firms and microbreweries. It further shows whether these firms see themselves as financially constrained

the firm to be financially constrained. About $69 \%$ state that these financing obstacles hold back their firms' growth. In contrast, only a quarter of the microbreweries appear to be financially constrained and stated that they are restricted in their growth due to lack of funding. Consequently, marijuana SMEs suffer from their lack of access to bank financing.

\subsubsection{Transaction services, bank lending, and other challenges}

Our survey results indicate that the lack of legal access to banking services restricts marijuana SMEs in both financing and transactions. We now assess the relative importance of the two functions and explore their effects compared to other common challenges of SMEs. Panel A of Table 9 shows the perceived benefits of banking services. When asked about the most useful banking service, over $50 \%$ of the respondents state deposit and savings accounts. Thereby, the banks' service for storing and safeguarding money is perceived as highly important. The access to bank lending $(\sim 26 \%)$ and money transfer services ( $24 \%)$ appear to be equally important to marijuana SMEs.

Panel B of Table 9 displays the major challenges marijuana SMEs face, including the lack of access to banking services. Tax rules are the dominant concern of 


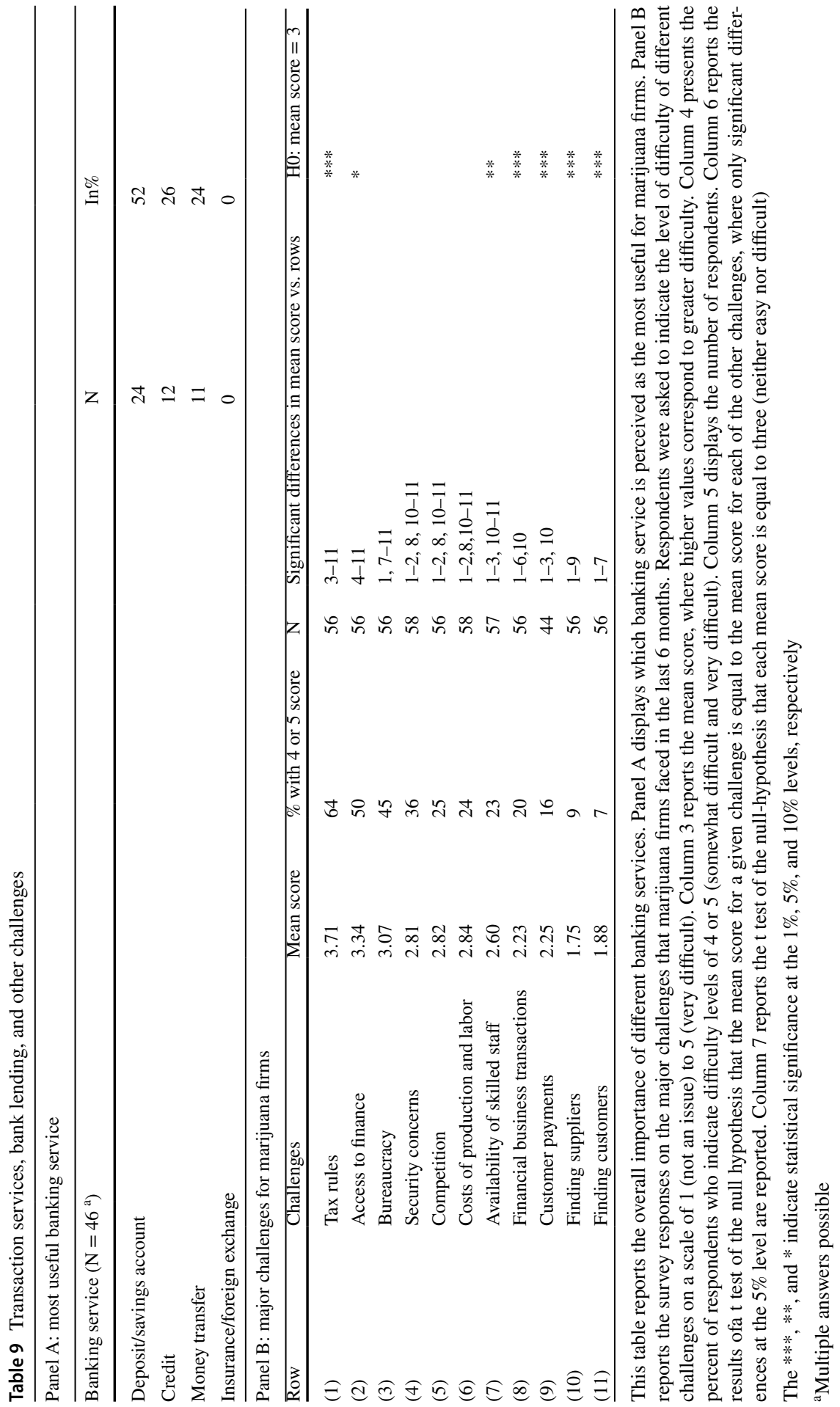


marijuana SMEs with $64 \%$ mentioning this as one of their main problems. ${ }^{6}$ Access to finance is the second major concern $(\sim 50 \%)$. This is in line with the previously stated results. Financial transactions with customers and/or suppliers are only a minor concern. It appears that marijuana SMEs have adapted to the legal restriction by using cash payments. However, the frequent handling of large cash transactions increases security concerns dramatically. Security is the fourth most important concern of marijuana SMEs and is even ranked higher than concerns regarding the attraction of customers or finding sufficiently skilled employees and suppliers. These security concerns in turn negatively affect the creditworthiness of the firm because the credit repayment is subject to theft, intensifying the financing problems.

To identify the major challenges that young SMEs typically face, US American microbreweries are used as a control, in Fig. 3. Bureaucracy is the dominant concern of microbreweries with $46 \%$ mentioning this as one of their main problems, followed by tax rules. This is consistent with the findings from marijuana SMEs. Although $38 \%$ of the surveyed microbreweries mentioned access to finance as the third major concern, they rated it on average significantly lower. With a mean value of 2.67 (compared to 3.34 for marijuana SMEs) access to finance appears to be rather a minor issue. This is also confirmed by the fact that finding customers is almost as challenging as getting financing for microbreweries. Looking at the handling of financial transactions and security concerns, the value of banking services becomes even more obvious. In contrast to the marijuana SMEs, none of the microbreweries rated customer payments or security as major concerns.

Table 10 reinforces the impressions from Fig. 3. Compared to similar SMEs with legal access to banking services, transactions (with customers and other firms) and getting additional funding are significantly more difficult for marijuana SMEs. Additionally, security concerns are considerably higher as a result of missing bank-based transaction services. ${ }^{7}$

As shown by Ayyagari et al. (2008), only obstacles related to finance, crime, and policy instability directly affect firms' growth. It appears that microbreweries do not face these obstacles. Most microbreweries $(\sim 75 \%)$ stated that the current business environment is not restricting their growth. In comparison, $69 \%$ of the surveyed marijuana SMEs are hindered in their growth because they lack widespread access to banking services.

In summary, our findings substantiate the importance of legal access to banking for young SMEs in developed countries. In particular, widespread access to banking services would alleviate the growth constraints for marijuana SMEs. Access to bank loans is needed to finance future operations whereas access to bank-based transaction services reduces the firms' risk, improves their operating performance, and increases the firms' creditworthiness.

\footnotetext{
${ }^{6}$ Since marijuana is a Schedule I controlled substance, the IRS has used section 280E to disallow marijuana firms from deducting their ordinary and necessary business expenses. The result is that marijuana firms face much higher taxes than similar companies in other industries.

${ }^{7}$ As previously mentioned, the significant difference in tax rules results from the huge tax burdens marijuana firms face.
} 


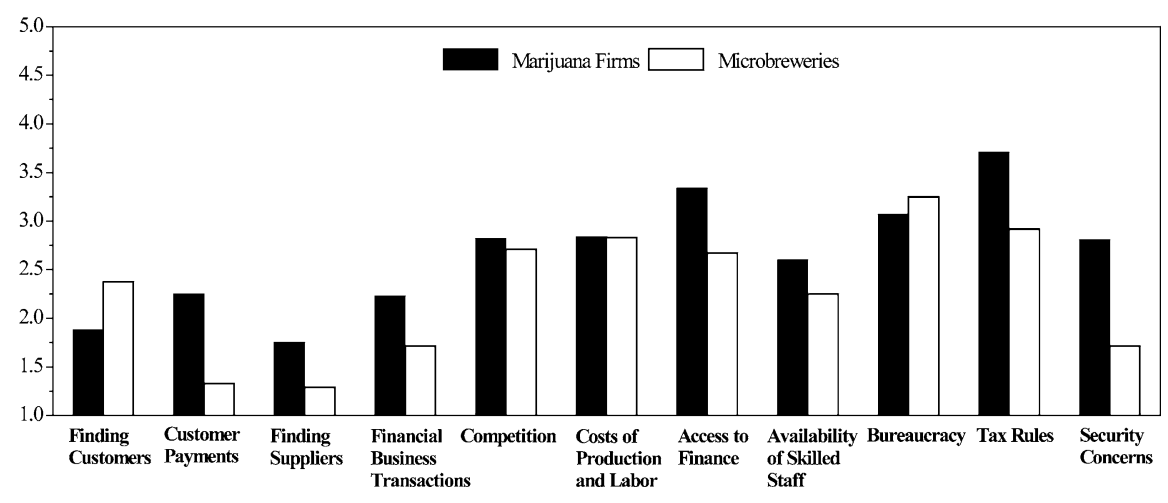

Fig. 3 Major challenges for marijuana SMEs and microbreweries

Table 10 Comparisons for challenges of marijuana SMEs and microbreweries

\begin{tabular}{|c|c|c|c|c|c|}
\hline \multirow[t]{2}{*}{ Challenges } & \multicolumn{2}{|c|}{ Marijuana firms } & \multicolumn{2}{|c|}{ Microbreweries } & \multirow{2}{*}{$\begin{array}{l}\mathrm{H} 0 \text { : equality } \\
\text { of means }\end{array}$} \\
\hline & Mean & St. dev & Mean & St. dev & \\
\hline Tax rules & 3.71 & 1.45 & 2.92 & 1.18 & $* *$ \\
\hline Access to finance & 3.34 & 1.43 & 2.67 & 1.63 & $*$ \\
\hline Bureaucracy & 3.07 & 1.43 & 3.25 & 1.26 & \\
\hline Security concerns & 2.81 & 1.33 & 1.71 & 0.81 & $* * *$ \\
\hline Competition & 2.82 & 1.13 & 2.71 & 1.30 & \\
\hline Costs of production and labor & 2.84 & 1.15 & 2.83 & 1.24 & \\
\hline Availability of skilled staff & 2.60 & 1.21 & 2.25 & 1.03 & \\
\hline Financial business transactions & 2.23 & 1.36 & 1.71 & 1.23 & $*$ \\
\hline Customer payments & 2.25 & 1.28 & 1.33 & 0.56 & $* * *$ \\
\hline Finding suppliers & 1.75 & 1.07 & 1.29 & 0.62 & $* *$ \\
\hline Finding customers & 1.88 & 0.99 & 2.38 & 1.13 & $*$ \\
\hline
\end{tabular}

This table reports the mean score and standard deviation of survey responses on the major challenges that marijuana firms and microbreweries faced in the last 6 months. Respondents were asked to indicate the level of difficulty of different challenges on a scale of 1 (not an issue) to 5 (very difficult). The last column reports the result of a Welch $t$ test of equal means between the two different firm groups

The ***, **, and * indicate a statistical significance difference in means at the $1 \%, 5 \%$, and $10 \%$ levels, respectively

\section{Critical assessment and further research}

In total, our empirical analysis gives significant insights into the value of banking services for developing industries in the United States, based on findings from the marijuana industry. In the event studies, we examined the value of legal banking access for the marijuana industry. In order to ensure that the results of the three event studies are not driven by any effects stemming from differences in the sample, we graphically analyzed the eight firms that are examined in all events and show that our main results are also valid for this 
subgroup (compare Fig. 4 in Appendix 3). ${ }^{8}$ Although we carefully selected events which affect the legality of the marijuana industry's access to banking, the changes in stock prices and the corresponding abnormal returns only reflect investors' changing expectations. Thus, it is only an indirect indicator for the valuation of legal banking access by the industry, which could be biased. For example, investors could incorrectly estimate firms' ability to cope with adverse regulatory developments, i.e. that the actual impact of the event is less positive/negative than investors expect. It is possible that our results are partly driven by other channels. The banking announcement may indicate the increased demand for marijuana and drive the results of the event studies through the demand channel rather than the value of banking services. In the future a more accurate value of banking access could be attained by analyzing a binding law change. Alternatively, in future studies, abnormal returns from the events could be compared to abnormal returns surrounding other industry (non-banking) announcements related to the marijuana industry. However, the only important other industry (non-banking) announcements that took place during the examined time frames were votes on legalization in several states. For Colorado, these took place back in November 2012, a time when investor interest in marijuana was low. For several other states, the vote on legalization coincided with the presidential election in 2016, making it impossible to estimate meaningful abnormal returns.

With the survey, we specifically examine the perspectives of SMEs that are directly involved in the production and distribution of marijuana, on the business challenges that arise from the denied banking access. As with all surveys, it is possible that our sample suffers from a bias. For example, respondents that maintain bank accounts illegally might be less likely to participate in the survey out of fear that their activity will be disclosed. Although the bias should be limited because complete anonymity was ensured; four out of five asked respondents filled out the survey and of those a large number illegally uses a bank account. The later work of Berger and Seegert (2020), a larger study, is also in line with the results presented here. As a result, although the survey sample size here was small, the findings appear to be representative. Officially reported marijuana firm data from Washington State also substantiates the relevance of our results (compare, Bhue 2018). It is also possible that some respondents systematically overstate the value of legal access to banking due to social desirability or their short firm history. Several types of questions, i.e. subjective, objective, direct and indirect questions, have been used to limit this bias. In addition, all results are robust for the subgroup of respondents that have worked at least 1 year for the firms (compare Tables 22, 23, 24, 25 and 26 in Appendix 5). In the survey, the high perceived value for bank-based financial transaction services is identified. Specifically, the heightened security risk as a results of large cash amounts is frequently cited. Now that marijuana has been legalized in over ten states, a larger multi-state study could be used to verify the general validity of the findings.

Based on the combined methods presented here, it can be discerned that the industry as a whole perceives legal banking access as highly desirable. Due to the inhomogeneity of the examined samples, it is not possible to directly link the worth of legal banking access identified in the event studies with the high valuation of bank financing transaction services by marijuana SMEs.

\footnotetext{
${ }^{8}$ Note that there are some differences in the results for the second and third event on single days. These differences can largely be traced back to the effect of averaging very few observations.
} 


\section{Conclusion}

This study uses a mixed-method approach to analyze the real economic benefits of legal banking services for the US marijuana industry. While this industry has access to the superior institutional environment of the United States, the conflict between federal and state laws prevents any legal banking access.

In an event study, we find statistically strong and economically significant value consequences around three events that are significant for determining the marijuana industry's future banking access. These results indicate that despite the superior institutional environment offered by a highly developed country, the marijuana industry still perceives widespread access to banking as crucial. In order to understand if financing and/ or transaction services are perceived as desirable by the industry, we conducted a comprehensive survey. Microbreweries (a similar industry in size and revenues) were used as a control. As expected, in our survey more young marijuana SMEs than microbreweries identified financing as challenging. Many marijuana SMEs struggle to find financing comparable to that offered by banks: cheap and reliable. As a result, they more often cited being financially constrained. This indicates that widespread access to bank lending would help marijuana firms grow. Surprisingly, after access to finance, security concerns were cited as one of the largest challenges facing marijuana SMEs. Contrarily, despite being in a similar industry segment, microbreweries do not consider security a concern. Without legal access to banking services, marijuana firms are forced to use cash to complete financial transactions. These transactions are perceived as inefficient and significantly increase security concerns due to large levels of cash present in the firms. Our results indicate that in addition to access to financing, SMEs consider access to efficient payment and transaction services as substantially important for alleviating their financial constraints and stimulating their growth. The insights initially provided here are further supported by an ongoing larger study from Berger and Seegert (2020).

In summary, based on our results, even in highly developed countries, the services of traditional banks remain desirable. In line with the large body of existing studies, SMEs still rely on financing from banks. Additionally, the marijuana industry identifies transaction services as one of the most desirable bank functions. From studies largely done in Kenya, the importance of transaction services was previously identified. In these studies, however, the widespread and successful use of solely a transaction service was examined. In line with the results here, one critical aspect of transaction services is an increase of security due to a reduction of large cash amounts. In the United States, similar transaction service providers exist. This fact in context with the research from Kenya, makes the marijuana industry's high valuation of bank's transaction services surprising. Based on the study here, this result cannot be conclusively explained. It is, however, possible that due to their long-standing presence, banks today play a too integral part in transaction processing within the United States, preventing widespread use of alternates.

\section{Appendix 1: Sample firms}

See Tables 11 and 12. 
Table 11 Sample firms

\begin{tabular}{|c|c|c|c|}
\hline Industry sector & $\begin{array}{l}\text { Event } 1 \\
\text { Company name }\end{array}$ & $\begin{array}{l}\text { Event } 2 \\
\text { Company name }\end{array}$ & $\begin{array}{l}\text { Event } 3 \\
\text { Company name }\end{array}$ \\
\hline Producer & & $\begin{array}{l}\text { GROWBLOX SCIENCES } \\
\text { UNITED CANNABIS }\end{array}$ & UNITED CANNABIS \\
\hline \multirow[t]{2}{*}{ Industrial } & $\begin{array}{l}\text { AERO GROW INT. } \\
\text { GREENGRO TECH. } \\
\text { GROWLIFE }\end{array}$ & $\begin{array}{l}\text { AERO GROW INT. } \\
\text { TERRA TECH } \\
\text { TWO RIV. WATER } \\
\text { FRMG. }\end{array}$ & $\begin{array}{l}\text { AERO GROW INT. } \\
\text { GROWGENERATION } \\
\text { KUSHCO HLDG. }\end{array}$ \\
\hline & $\begin{array}{l}\text { TERRA TECH } \\
\text { TWO RIV. WATER } \\
\text { FRMG. }\end{array}$ & & $\begin{array}{l}\text { TERRA TECH } \\
\text { TWO RIV. WATER FRMG. }\end{array}$ \\
\hline \multirow[t]{8}{*}{ Pharma/research } & $\begin{array}{l}\text { 22ND CENTURY } \\
\text { GROUP }\end{array}$ & $\begin{array}{l}\text { 22ND CENTURY } \\
\text { GROUP }\end{array}$ & 22ND CENTURY GROUP \\
\hline & ARENA PHARMA. & ARENA PHARMA. & ARENA PHARMA. \\
\hline & CV SCIENCES & CARA THERAPEUTICS & AXIM BIOTECH. \\
\hline & $\begin{array}{l}\text { INSYS THERAPEUTICS } \\
\text { NEUTRA }\end{array}$ & $\begin{array}{l}\text { CV SCIENCES } \\
\text { EMERALD BIOSCI- } \\
\text { ENCE }\end{array}$ & $\begin{array}{l}\text { CANNABICS PHARMA. } \\
\text { CANNAPHARMARX }\end{array}$ \\
\hline & PAZOO & INSYS THERAPEUTICS & CARA THERAPEUTICS \\
\hline & $\begin{array}{l}\text { PHARMACYTE BIO- } \\
\text { TECH. }\end{array}$ & NEUTRA & CV SCIENCES \\
\hline & VERDE SCIENCE & PAZOO & EMERALD BIOSCIENCE \\
\hline & & ZYNERBA PHARMA. & $\begin{array}{l}\text { INSYS THERAPEUTICS } \\
\text { ZYNERBA PHARMA. }\end{array}$ \\
\hline \multirow[t]{3}{*}{ Consulting } & CHUMA HLDG. & AMERICANN & AMERICANN \\
\hline & DIRECTVIEW HLDG. & GROW CAPITAL & MARIMED \\
\hline & $\begin{array}{l}\text { GREEN TECH. SLTN. } \\
\text { ML CAPITAL GROUP }\end{array}$ & MARIMED & $\begin{array}{l}\text { MJ HLDG. } \\
\text { STWC HLDG. }\end{array}$ \\
\hline \multirow[t]{5}{*}{ Technology } & AVT & DIGIPATH & DIGIPATH \\
\hline & ENDEXX & LIFELOC TECH. & ENDEXX \\
\hline & MCIG & MASSROOTS & LIFELOC TECH. \\
\hline & NHALE & MYDX & TECHCARE \\
\hline & TECHCARE & TECHCARE & \\
\hline Real estate & $\begin{array}{l}\text { GENERAL CANNABIS } \\
\text { ZONED PROPERTIES }\end{array}$ & GENERAL CANNABIS & $\begin{array}{l}\text { GENERAL CANNABIS } \\
\text { INNOV. INDL. PROPS. }\end{array}$ \\
\hline \multirow[t]{4}{*}{ Consumer } & $\begin{array}{l}\text { FOREVERGREEN } \\
\text { WWD. }\end{array}$ & CANNABIS SATIVA & CANNABIS SATIVA \\
\hline & $\begin{array}{l}\text { HEALTHIER CHOICES } \\
\text { MAN. }\end{array}$ & EARTH SCIENCE TECH. & CBDMD (ASE) \\
\hline & HEMP & $\begin{array}{l}\text { FOREVERGREEN } \\
\text { WWD. }\end{array}$ & EARTH SCIENCE TECH. \\
\hline & VAPE HLDG. & $\begin{array}{l}\text { HEALTHIER CHOICES } \\
\text { MAN. } \\
\text { ROCKY MOUNT. HIGH }\end{array}$ & FOREVERGREEN WWD. \\
\hline
\end{tabular}

This table displays the firm samples for the event studies 
Table 12 Sample characteristics event study

\begin{tabular}{llll}
\hline Panel A: by industry sector & & \\
\hline Industry sector & Event 1 & Event 2 & Event 3 \\
& {$[\mathrm{N}=28]$} & {$[\mathrm{N}=28]$} & {$[\mathrm{N}=30]$} \\
\hline Producer & 0 & 2 & 1 \\
Industrial & 5 & 3 & 5 \\
Pharma/research & 8 & 8 & 10 \\
Consulting & 4 & 3 & 4 \\
Technology & 5 & 5 & 4 \\
Real estate & 2 & 1 & 2 \\
Consumer & 4 & 6 & 4
\end{tabular}

Panel B: by listing type

\begin{tabular}{llcc}
\hline Stock market & Event 1 & Event 2 & Event 3 \\
& {$[\mathrm{N}=28]$} & {$[\mathrm{N}=28]$} & {$[\mathrm{N}=30]$} \\
\hline OTC PINK & 16 & 7 & 5 \\
OTCQB & 7 & 13 & 13 \\
OTCQX & 2 & 3 & 4 \\
NASDAQ & 2 & 4 & 5 \\
NYSE & 1 & 1 & 3 \\
\hline
\end{tabular}

This table displays the distribution of marijuana stocks by industry sector and by listing type. The industry sectors are adopted from Bloomberg. Producers are medical marijuana growers and recreational cultivators. Industrial firms are manufacturers of equipment or growing facilities used by the marijuana industry. Pharmaceutical research firms develop and/or research cannabis-based therapeutics and medicines. Consulting firms provide consulting, management, marketing, and/or financial services to the marijuana industry. Technology firms develop marijuana breathalyzers and/or provide software and technology solutions to the marijuana industry. Real estate firms acquire, lease, and/or develop real estate properties and growing facilities for the marijuana industry. Consumer firms are producers and manufacturers of hemp- or cannabis-based products, such as nutraceuticals, fibers, fabrics, and/or vaporization products 


\section{Appendix 2: Survey}

\section{A: Company Background Information}

1. In which U.S. state are your headquarters located?

2. In which year did your company start operating in the marijuana industry?

3. How long have you been with the company?

4. What is your position in the company?

5. How many people does your company currently employ in full-time equivalents?

6. Who owns the largest stake in the company?

$\square$ one owner (yourself or another single person)

$\square$ multiple people (e.g., a family or several entrepreneurs)

$\square$ another company

$\square$ public shareholders (it is listed on the stock market)

$\square$ venture capital enterprises or business angels

$\square$ other, please specify:

7. Which sector of the marijuana industry is your company currently in? (If you have businesses in more than one, please choose the one in which you spend most of your time/ have the most active role.)

$\square$ wholesale grower

$\square$ infused product maker (edibles, topicals, concentrates, etc.)

$\square$ dispensary or recreational store with integrated grow or processing

$\square$ dispensary or recreational store without integrated grow or processing

$\square$ testing lab

$\square$ ancillary services (i.e., law firms, consultants, accountants, education, etc.)

$\square$ ancillary technology or products (i.e., consumption devices, software, lighting, etc.)

8. What was the annual turnover of your company within the last year?

up to $\$ 100,000$

over $\$ 100,000$ and up to $\$ 500,000$

over $\$ 500,000$ and up to $\$ 1$ million

over $\$ 1$ million and up to $\$ 5$ million

over $\$ 10$ million and up to $\$ 50$ million

over $\$ 10$ million and up to $\$ 50$ million

over $\$ 50$ million 
9. Over the past two years, how much did your company grow on average per year in terms of turnover?
$\square$ over $50 \%$
$\square$ between $20 \%$ and $50 \%$
$\square$ less than $20 \%$
$\square$ stayed about the same size
$\square$ became smaller

10. Did you (at least) break even last year?

$\square$ yes
$\square$ no

11. How difficult have the following been for your company in the last six months?

\begin{tabular}{|c|c|c|c|c|c|}
\hline & $\begin{array}{l}\text { not } \\
\text { an } \\
\text { issue }\end{array}$ & & & & $\begin{array}{l}\text { very } \\
\text { difficult }\end{array}$ \\
\hline & 1 & 2 & 3 & 4 & 5 \\
\hline finding customers & $\square$ & $\square$ & $\square$ & $\square$ & $\square$ \\
\hline customer payments & $\square$ & $\square$ & $\square$ & $\square$ & $\square$ \\
\hline finding suppliers & $\square$ & $\square$ & $\square$ & $\square$ & $\square$ \\
\hline $\begin{array}{l}\text { financial business transactions } \\
\text { (e.g., paying employees, vendors, etc.) }\end{array}$ & $\square$ & $\square$ & $\square$ & $\square$ & $\square$ \\
\hline competition & $\square$ & $\square$ & $\square$ & $\square$ & $\square$ \\
\hline costs of production and labor & $\square$ & $\square$ & $\square$ & $\square$ & $\square$ \\
\hline $\begin{array}{l}\text { access to finance } \\
\text { (financing your business) }\end{array}$ & $\square$ & $\square$ & $\square$ & $\square$ & $\square$ \\
\hline $\begin{array}{l}\text { availability of skilled staff } \\
\text { or experienced managers }\end{array}$ & $\square$ & $\square$ & $\square$ & $\square$ & $\square$ \\
\hline $\begin{array}{l}\text { bureaucracy } \\
\text { (e.g., business license application) }\end{array}$ & $\square$ & $\square$ & $\square$ & $\square$ & $\square$ \\
\hline tax rules & $\square$ & $\square$ & $\square$ & $\square$ & $\square$ \\
\hline security concerns & $\square$ & $\square$ & $\square$ & $\square$ & $\square$ \\
\hline other, please specify: & $\square$ & $\square$ & $\square$ & $\square$ & $\square$ \\
\hline
\end{tabular}

B: Access to Banking and Financing of Your Company

1. Which banking service would be most useful for your company?
$\square$ deposit/savings account
$\square$ money transfer
$\square$ foreign exchange
$\square$ credit
$\square$ insurance 
2. Does your cannabis company currently have a business account with an U.S. American bank or credit union?

yes, direct relationship with the bank/credit union

$\square$ yes, via a third party (i.e., holding companies, financial intermediaries, etc.)

no (please continue with question 4)

3. How stable do you consider your company's banking relationship?

terminable

short-term

long-term

4. Have you ever been rejected by a bank, i.e., were unable to open a bank account, or the bank closed your account?

yes, please specify:

no

5. How do you receive most of your revenue?

cash

electronic funds transfer via a bank (e.g., direct deposit/debit)

check

$\square$ electronic transfer via a non-bank third party (e.g., Bitcoin)

other, please specify:

6. How do you pay most of your bills?

cash

electronic funds transfer via a bank (e.g., direct deposit/debit)

check

electronic transfer via a non-bank third party (e.g., Bitcoin)

other, please specify: 
7. What in your opinion would be the biggest benefit of access to banking in regards to money transactions for your company?

$\begin{array}{lccccc} & \begin{array}{c}\text { not } \\ \text { beneficial }\end{array} & & & \begin{array}{c}\text { very } \\ \text { beneficial }\end{array} \\ & \mathbf{1} & \mathbf{2} & \mathbf{3} & \mathbf{4} & \mathbf{5} \\ \text { reduced cost of } & \square & \square & \square & \square & \square \\ \text { financial transactions } & & & & & \\ \text { reduced time of } & \square & \square & \square & \square & \square \\ \text { financial transactions } & \square & \square & \square & \square & \square \\ \text { more satisfied suppliers } & \square & \square & \square & \square & \square \\ \text { more satisfied customers } & \square & & & & \end{array}$

8. Are the following sources of financing relevant to your company?

private loans

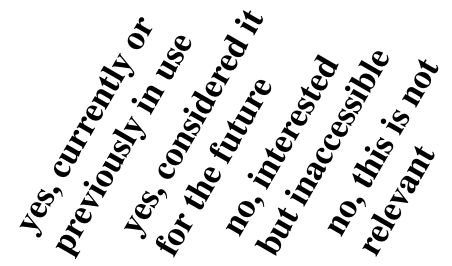

(e.g., from family and friends)

loans from (related) companies

debt securities issued

(e.g., corporate bonds issued by

your company)

private equity capital

(venture capital or business angels)

public equity capital (stocks)

credit line, bank overdraft or credit card overdrafts

bank loans

trade credit, factoring, or

leasing or hire purchase

internal funds

(resulting for instance from savings,

retained earnings or sales assets)

other, specify: 
9. What type of external financing would you prefer most to help your company grow?

$\square$ equity capital (e.g., venture capital, business angels or stocks)

$\square$ bank loans

$\square$ loans from other sources (e.g., trade credit, related company, or family)

$\square$ not applicable because of sufficient internal funds (e.g., savings, or sales assets)

other, please specify:

10. What would be your first reaction in the case of unexpected costs (e.g., replacement of storage furniture, new transport vehicles, etc.)?

$\square$ raising capital (e.g., from owners)

cut back investments

$\square$ close the business

$\square$ delay wage payments

delay payments of suppliers

increase the price of products

layoff employees

other, please specify:

11. Is the current business financing environment (i.e., the limited access to banking) restricting growth opportunities for your company?

yes, please specify:

no

\section{Appendix 3: Robustness tests: event studies}

\section{Event 1: Guidance Fin-2014-G001}

See Tables 13, 14, 15. 
Table 13 Event 1 with the standardized cross-sectional test by Kolari and Pynnönen (2010)

Panel A: zero-return benchmark

\begin{tabular}{|c|c|c|c|c|c|c|c|c|}
\hline & \multirow{2}{*}{$\begin{array}{l}\text { Average abnor- } \\
\text { mal returns }(\%)\end{array}$} & \multirow[t]{2}{*}{$t_{K P}$} & \multirow{2}{*}{$\begin{array}{l}\text { Positive/no } \\
\text { change/negative }\end{array}$} & \multicolumn{5}{|c|}{ Cumulative average abnormal returns } \\
\hline & & & & $(-1,2)$ & $(-1,1)$ & $(0,1)$ & $(0,2)$ & $(1,2)$ \\
\hline$t-2$ & 1.86 & 1.06 & $15 / 2 / 11$ & & & & & \\
\hline$t-1$ & 4.17 & $2.58 * * *$ & $18 / 2 / 8$ & $9.32 \%$ & $10.61 \%$ & $6.44 \%$ & $5.15 \%$ & $0.77 \%$ \\
\hline Event day & 4.38 & $2.28 * *$ & $16 / 5 / 7$ & $2.58 * *$ & $2.91 * * *$ & $2.51 * *$ & $1.78^{*}$ & 0.30 \\
\hline $\mathrm{t}+1$ & 2.06 & 0.98 & $14 / 2 / 12$ & & & & & \\
\hline$t+2$ & -1.29 & -0.88 & $9 / 1 / 18$ & & & & & \\
\hline
\end{tabular}

Panel B: market benchmark of S\&P 500 Index

\begin{tabular}{|c|c|c|c|c|c|c|c|c|}
\hline & \multirow{2}{*}{$\begin{array}{l}\text { Average abnor- } \\
\text { mal returns (\%) }\end{array}$} & \multirow{2}{*}{$t_{K P}$} & \multirow[t]{2}{*}{ Positive/negative } & \multicolumn{5}{|c|}{ Cumulative average abnormal returns } \\
\hline & & & & $(-1,2)$ & $(-1,1)$ & $(0,1)$ & $(0,2)$ & $(1,2)$ \\
\hline$t-2$ & 0.91 & 0.52 & $13 / 15$ & & & & & \\
\hline $\mathrm{t}-1$ & 3.20 & $1.85^{*}$ & $16 / 12$ & $5.47 \%$ & $7.71 \%$ & $4.51 \%$ & $2.27 \%$ & $-1.14 \%$ \\
\hline Event day & 3.41 & $1.82 *$ & $14 / 14$ & 1.49 & $2.06^{* *}$ & $1.77 *$ & 0.80 & -0.45 \\
\hline $\mathrm{t}+1$ & 1.10 & 0.52 & $14 / 14$ & & & & & \\
\hline $\mathrm{t}+2$ & -2.24 & -1.50 & $7 / 21$ & & & & & \\
\hline \multicolumn{9}{|c|}{ Panel C: market benchmark of S\&P 600 Food, Beverage, \& Tobacco Index } \\
\hline & \multirow{2}{*}{$\begin{array}{l}\text { Average abnor- } \\
\text { mal returns }(\%)\end{array}$} & \multirow[t]{2}{*}{$t_{K P}$} & \multirow[t]{2}{*}{ Positive/negative } & \multicolumn{5}{|c|}{ Cumulative average abnormal returns } \\
\hline & & & & $(-1,2)$ & $(-1,1)$ & $(0,1)$ & $(0,2)$ & $(1,2)$ \\
\hline$t-2$ & 0.92 & 0.52 & $13 / 15$ & & & & & \\
\hline $\mathrm{t}-1$ & 3.46 & $1.83^{*}$ & $16 / 12$ & $5.67 \%$ & $8.02 \%$ & $4.56 \%$ & $2.21 \%$ & $-1.23 \%$ \\
\hline Event day & 3.44 & $1.84^{*}$ & $14 / 14$ & 1.56 & $2.11 * *$ & $1.83 *$ & 0.79 & -0.48 \\
\hline$t+1$ & 1.12 & 0.53 & $14 / 14$ & & & & & \\
\hline$t+2$ & -2.35 & -1.54 & $8 / 20$ & & & & & \\
\hline
\end{tabular}

This table displays the event study results for the Guidance Fin-2014-G001. The average abnormal returns (AARs) correspond to the excess returns with respect to three different benchmarks. In panel A, the AARs are calculated against the zero-return benchmark; panel B uses the S\&P 500 Index as a broad market benchmark; panel $\mathrm{C}$ relies on the SMEs in the food, beverage, and tobacco industries, by using the S\&P 600 Food, Beverage, \& Tobacco Index as the market benchmark. Significance is calculated based on the two-sided standardized cross-sectional test by Kolari and Pynnönen (2010). Column 3 displays the number of individual marijuana firms that have abnormal positive (negative) returns on the specific trading day. The cumulative average abnormal returns are calculated based on five different event windows

The $* * *, * *$, and $*$ represent significance at the $1 \%, 5 \%$, and the $10 \%$ levels 
Table 14 Event 1 with the parametric test by Boehmer et al. (1991)

Panel A: zero-return benchmark

\begin{tabular}{|c|c|c|c|c|c|c|c|c|}
\hline & \multirow{2}{*}{$\begin{array}{l}\text { Average abnor- } \\
\text { mal returns (\%) }\end{array}$} & \multirow[t]{2}{*}{$t_{B M P}$} & \multirow{2}{*}{$\begin{array}{l}\text { Positive/no } \\
\text { change/negative }\end{array}$} & \multicolumn{5}{|c|}{ Cumulative average abnormal returns } \\
\hline & & & & $(-1,2)$ & $(-1,1)$ & $(0,1)$ & $(0,2)$ & $(1,2)$ \\
\hline $\mathrm{t}-2$ & 1.86 & 1.18 & $15 / 2 / 11$ & & & & & \\
\hline $\mathrm{t}-1$ & 4.17 & $2.38 * *$ & $18 / 2 / 8$ & $9.32 \%$ & $10.61 \%$ & $6.44 \%$ & $5.15 \%$ & $0.77 \%$ \\
\hline Event day & 4.38 & $2.18 * *$ & $16 / 5 / 7$ & $2.49 * *$ & $3.14 * * *$ & $2.48 * *$ & 1.48 & 0.00 \\
\hline$t+1$ & 2.06 & 0.76 & $14 / 2 / 12$ & & & & & \\
\hline$t+2$ & -1.29 & -0.75 & $9 / 1 / 18$ & & & & & \\
\hline
\end{tabular}

Panel B: market benchmark of S\&P 500 Index

\begin{tabular}{|c|c|c|c|c|c|c|c|c|}
\hline & \multirow{2}{*}{$\begin{array}{l}\text { Average abnor- } \\
\text { mal returns (\%) }\end{array}$} & \multirow[t]{2}{*}{$t_{B M P}$} & \multirow[t]{2}{*}{ Positive/negative } & \multicolumn{5}{|c|}{ Cumulative average abnormal returns } \\
\hline & & & & $(-1,2)$ & $(-1,1)$ & $(0,1)$ & $(0,2)$ & $(1,2)$ \\
\hline$t-2$ & 0.91 & 0.57 & $13 / 15$ & & & & & \\
\hline $\mathrm{t}-1$ & 3.20 & 1.35 & $16 / 12$ & $5.47 \%$ & $7.71 \%$ & $4.51 \%$ & $2.27 \%$ & $-1.14 \%$ \\
\hline $\begin{array}{r}\text { Event } \\
\text { day }\end{array}$ & 3.41 & 1.56 & $14 / 14$ & 0.96 & $1.77 *$ & 1.47 & 0.38 & -0.77 \\
\hline$t+1$ & 1.10 & 0.14 & $14 / 14$ & & & & & \\
\hline $\mathrm{t}+2$ & -2.24 & -1.35 & $7 / 21$ & & & & & \\
\hline
\end{tabular}

Panel C: market benchmark of S\&P 600 Food, Beverage, \& Tobacco Index

\begin{tabular}{|c|c|c|c|c|c|c|c|c|}
\hline & \multirow{2}{*}{$\begin{array}{l}\text { Average abnor- } \\
\text { mal returns }(\%)\end{array}$} & \multirow[t]{2}{*}{$t_{B M P}$} & \multirow[t]{2}{*}{ Positive/ Negative } & \multicolumn{5}{|c|}{ Cumulative average abnormal returns } \\
\hline & & & & $(-1,2)$ & $(-1,1)$ & $(0,1)$ & $(0,2)$ & $(1,2)$ \\
\hline $\mathrm{t}-2$ & 0.92 & 0.56 & $13 / 15$ & & & & & \\
\hline $\mathrm{t}-1$ & 3.46 & 1.29 & $16 / 12$ & $5.67 \%$ & $8.02 \%$ & $4.56 \%$ & $2.21 \%$ & $-1.23 \%$ \\
\hline $\begin{array}{r}\text { Event } \\
\text { day }\end{array}$ & 3.44 & $1.69 *$ & $14 / 14$ & 1.04 & $1.81^{*}$ & 1.59 & 0.46 & -0.77 \\
\hline$t+1$ & 1.12 & 0.14 & $14 / 14$ & & & & & \\
\hline$t+2$ & -2.35 & -1.34 & $8 / 20$ & & & & & \\
\hline
\end{tabular}

This table displays the event study results for the Guidance Fin-2014-G001. The average abnormal returns (AARs) correspond to the excess returns with respect to three different benchmarks. In panel A, the AARs are calculated against the zero-return benchmark; panel B uses the S\&P 500 Index as a broad market benchmark; panel $\mathrm{C}$ relies on the firms in the food, beverage, and tobacco industries, by using the S\&P 600 Food, Beverage, \& Tobacco Index as the market benchmark. Significance is calculated based on the two-sided parametric test by Boehmer et al. (1991). Column 3 displays the number of individual marijuana firms that have abnormal positive (negative) returns on the specific trading day. The cumulative average abnormal returns are calculated based on five different event windows

The ***,**, and * represent significance at the $1 \%, 5 \%$, and the $10 \%$ levels 
Table 15 Event 1 with the non-parametric rank test by Corrado (1989) and Corrado and Zivney (1992)

Panel A: zero-return benchmark

\begin{tabular}{|c|c|c|c|c|c|c|c|c|}
\hline & \multirow{2}{*}{$\begin{array}{l}\text { Average abnor- } \\
\text { mal returns }(\%)\end{array}$} & \multirow[t]{2}{*}{$t_{C}$} & \multirow{2}{*}{$\begin{array}{l}\text { Positive/no } \\
\text { change/negative }\end{array}$} & \multicolumn{5}{|c|}{ Cumulative average abnormal returns } \\
\hline & & & & $(-1,2)$ & $(-1,1)$ & $(0,1)$ & $(0,2)$ & $(1,2)$ \\
\hline $\mathrm{t}-2$ & 1.86 & 0.93 & $15 / 2 / 11$ & & & & & \\
\hline$t-1$ & 4.17 & $2.09 * *$ & $18 / 2 / 8$ & $9.32 \%$ & $10.61 \%$ & $6.44 \%$ & $5.15 \%$ & $0.77 \%$ \\
\hline Event day & 4.38 & $1.69^{*}$ & $16 / 5 / 7$ & 1.23 & $2.43 * *$ & 1.50 & 0.21 & -0.94 \\
\hline$t+1$ & 2.06 & 0.43 & $14 / 2 / 12$ & & & & & \\
\hline $\mathrm{t}+2$ & -1.29 & $-1.76^{*}$ & $9 / 1 / 18$ & & & & & \\
\hline
\end{tabular}

Panel B: market benchmark of S\&P 500 Index

\begin{tabular}{|c|c|c|c|c|c|c|c|c|}
\hline & \multirow{2}{*}{$\begin{array}{l}\text { Average abnor- } \\
\text { mal returns }(\%)\end{array}$} & \multirow[t]{2}{*}{$t_{C}$} & \multirow{2}{*}{$\begin{array}{l}\text { Positive/nega- } \\
\text { tive }\end{array}$} & \multicolumn{5}{|c|}{ Cumulative average abnormal returns } \\
\hline & & & & $(-1,2)$ & $(-1,1)$ & $(0,1)$ & $(0,2)$ & $(1,2)$ \\
\hline $\mathrm{t}-2$ & 0.91 & 1.07 & $13 / 15$ & & & & & \\
\hline $\mathrm{t}-1$ & 3.20 & $1.74 *$ & $16 / 12$ & $5.47 \%$ & $7.71 \%$ & $4.51 \%$ & $2.27 \%$ & $-1.14 \%$ \\
\hline Event day & 3.41 & 1.31 & $14 / 14$ & 0.86 & $1.99 * *$ & 1.21 & -0.01 & -0.94 \\
\hline $\mathrm{t}+1$ & 1.10 & 0.39 & $14 / 14$ & & & & & \\
\hline $\mathrm{t}+2$ & -2.24 & $-1.72 *$ & $7 / 21$ & & & & & \\
\hline
\end{tabular}

Panel C: market benchmark of S\&P 600 Food, Beverage, \& Tobacco Index

\begin{tabular}{|c|c|c|c|c|c|c|c|c|}
\hline & \multirow{2}{*}{$\begin{array}{l}\text { Average abnor- } \\
\text { mal returns }(\%)\end{array}$} & \multirow[t]{2}{*}{$t_{C}$} & \multirow{2}{*}{$\begin{array}{l}\text { Positive/nega- } \\
\text { tive }\end{array}$} & \multicolumn{5}{|c|}{ Cumulative average abnormal returns } \\
\hline & & & & $(-1,2)$ & $(-1,1)$ & $(0,1)$ & $(0,2)$ & $(1,2)$ \\
\hline $\mathrm{t}-2$ & 0.92 & 0.94 & $13 / 15$ & & & & & \\
\hline $\mathrm{t}-1$ & 3.46 & $1.78^{*}$ & $16 / 12$ & $5.67 \%$ & $8.02 \%$ & $4.56 \%$ & $2.21 \%$ & $-1.23 \%$ \\
\hline Event day & 3.44 & $1.68^{*}$ & $14 / 14$ & 0.90 & $2.23 * *$ & 1.46 & 0.01 & -1.18 \\
\hline $\mathrm{t}+1$ & 1.12 & 0.39 & $14 / 14$ & & & & & \\
\hline$t+2$ & -2.35 & $-2.06^{* *}$ & $8 / 20$ & & & & & \\
\hline
\end{tabular}

This table displays the event study results for the Guidance Fin-2014-G001. The average abnormal returns (AARs) correspond to the excess returns with respect to three different benchmarks. In panel A, the AARs are calculated against the zero-return benchmark; panel B uses the S\&P 500 Index as a broad market benchmark; panel $\mathrm{C}$ relies on the firms in the food, beverage, and tobacco industries, by using the S\&P 600 Food, Beverage, \& Tobacco Index as the market benchmark. Significance is calculated based on the non-parametric rank test by Corrado (1989) and Corrado and Zivney (1992). Column 3 displays the number of individual marijuana firms that have abnormal positive (negative) returns on the specific trading day. The cumulative average abnormal returns are calculated based on five different event windows

The $* * *, * *$, and $*$ represent significance at the $1 \%, 5 \%$, and the $10 \%$ levels 


\section{Event 2: the Fourth Corner Credit Union case}

See Tables 16, 17 and 18.

Table 16 Event 2 with the standardized cross-sectional test by Kolari and Pynnönen (2010)

\begin{tabular}{|c|c|c|c|c|c|c|c|c|}
\hline \multicolumn{9}{|c|}{ Panel A: zero-return benchmark } \\
\hline & \multirow{2}{*}{$\begin{array}{l}\text { Average } \\
\text { abnormal } \\
\text { returns }(\%)\end{array}$} & \multirow[t]{2}{*}{$t_{K P}$} & \multirow{2}{*}{$\begin{array}{l}\text { Positive/ } \\
\text { no change/ } \\
\text { negative }\end{array}$} & \multicolumn{5}{|c|}{ Cumulative average abnormal returns } \\
\hline & & & & $(-1,2)$ & $(-1,1)$ & $(0,1)$ & $(0,2)$ & $(1,2)$ \\
\hline $\mathrm{t}-2$ & 3.44 & 1.32 & $13 / 6 / 9$ & & & & & \\
\hline $\mathrm{t}-1$ & 3.09 & 1.20 & $9 / 6 / 13$ & $-4.76 \%$ & $-0.92 \%$ & $-4.01 \%$ & $-7.85 \%$ & $-5.15 \%$ \\
\hline Event day & -2.70 & -1.03 & $11 / 4 / 13$ & -1.27 & -0.26 & -1.33 & $-2.18^{* *}$ & $-2.53 * *$ \\
\hline$t+1$ & -1.31 & -1.00 & $6 / 6 / 16$ & & & & & \\
\hline$t+2$ & -3.84 & $-2.07 * *$ & $7 / 5 / 16$ & & & & & \\
\hline
\end{tabular}

Panel B: market benchmark of S\&P 500 Index

\begin{tabular}{|c|c|c|c|c|c|c|c|c|}
\hline & \multirow{2}{*}{$\begin{array}{l}\text { Average abnor- } \\
\text { mal returns }(\%)\end{array}$} & \multirow[t]{2}{*}{$t_{K P}$} & \multirow{2}{*}{$\begin{array}{l}\text { Positive/ } \\
\text { negative }\end{array}$} & \multicolumn{5}{|c|}{ Cumulative average abnormal returns } \\
\hline & & & & $(-1,2)$ & $(-1,1)$ & $(0,1)$ & $(0,2)$ & $(1,2)$ \\
\hline$t-2$ & 3.71 & 1.46 & $14 / 14$ & & & & & \\
\hline $\mathrm{t}-1$ & 3.45 & 1.34 & $11 / 17$ & $-3.50 \%$ & $-0.14 \%$ & $-3.59 \%$ & $-6.95 \%$ & $-4.35 \%$ \\
\hline Event day & -2.60 & -0.99 & $14 / 14$ & -0.94 & -0.04 & -1.21 & $-1.93^{*}$ & $-1.94^{*}$ \\
\hline$t+1$ & -0.99 & -0.75 & $11 / 17$ & & & & & \\
\hline$t+2$ & -3.36 & $-1.69 *$ & $12 / 16$ & & & & & \\
\hline
\end{tabular}

Panel C: market benchmark of S\&P 600 Food, Beverage, \& Tobacco Index

\begin{tabular}{|c|c|c|c|c|c|c|c|c|}
\hline & \multirow{2}{*}{$\begin{array}{l}\text { Average abnor- } \\
\text { mal returns }(\%)\end{array}$} & \multirow[t]{2}{*}{$t_{K P}$} & \multirow{2}{*}{$\begin{array}{l}\text { Positive/ } \\
\text { nega- } \\
\text { tive }\end{array}$} & \multicolumn{5}{|c|}{ Cumulative average abnormal returns } \\
\hline & & & & $(-1,2)$ & $(-1,1)$ & $(0,1)$ & $(0,2)$ & $(1,2)$ \\
\hline $\mathrm{t}-2$ & 3.60 & 1.40 & $16 / 12$ & & & & & \\
\hline $\mathrm{t}-1$ & 3.50 & 1.34 & $11 / 17$ & $-3.78 \%$ & $-0.17 \%$ & $-3.67 \%$ & $-7.28 \%$ & $-4.80 \%$ \\
\hline Event day & -2.48 & -0.95 & $12 / 16$ & -1.01 & -0.05 & -1.22 & $-2.03^{* *}$ & $-2.34 * *$ \\
\hline $\mathrm{t}+1$ & -1.19 & -0.91 & $12 / 16$ & & & & & \\
\hline$t+2$ & -3.61 & $-1.93 *$ & $8 / 20$ & & & & & \\
\hline
\end{tabular}

This table displays the event study results around the court ruling against the Fourth Corner Credit Union. The average abnormal returns (AARs) correspond to the excess returns with respect to three different benchmarks. In panel A, the AARs are calculated against the zero-return benchmark; panel B uses the S\&P 500 Index as a broad market benchmark; panel $\mathrm{C}$ relies on the firms in the food, beverage, and tobacco industries, by using the S\&P 600 Food, Beverage, \& Tobacco Index as the market benchmark. Significance is calculated based on the two-sided standardized cross-sectional test by Kolari and Pynnönen (2010). Column 3 displays the number of individual marijuana firms that have abnormal positive (negative) returns on the specific trading day. The cumulative average abnormal returns are calculated based on five different event windows

The $* * *, * *$, and $*$ represent significance at the $1 \%, 5 \%$, and the $10 \%$ levels 
Table 17 Event 2 with the parametric test by Boehmer et al. (1991)

Panel A: zero-return benchmark

\begin{tabular}{lccllllll}
\hline & $\begin{array}{l}\text { Average } \\
\text { abnormal } \\
\text { returns }(\%)\end{array}$ & $t_{B M P}$ & $\begin{array}{l}\text { Positive/ } \\
\text { no change/ }\end{array}$ & & \multicolumn{5}{l}{ Cumulative average abnormal returns } \\
\cline { 6 - 8 } & negative & $(-1,2)$ & $(-1,1)$ & $(0,1)$ & $(0,2)$ & $(1,2)$ \\
\hline $\mathrm{t}-2$ & 3.44 & 1.14 & $13 / 6 / 9$ & & & & & \\
$\mathrm{t}-1$ & 3.09 & 0.65 & $9 / 6 / 13$ & $-4.76 \%$ & $-0.92 \%$ & $-4.01 \%$ & $-7.85 \%$ & $-5.15 \%$ \\
Event day & -2.70 & -0.66 & $11 / 4 / 13$ & -1.62 & -0.48 & -1.22 & $-2.43^{* *}$ & $-2.95^{* * *}$ \\
$\mathrm{t}+1$ & -1.31 & -1.17 & $6 / 6 / 16$ & & & & & \\
$\mathrm{t}+2$ & -3.84 & $-2.30^{* * *}$ & $7 / 5 / 16$ & & & & & \\
\hline
\end{tabular}

Panel B: market benchmark of S\&P 500 Index

\begin{tabular}{|c|c|c|c|c|c|c|c|c|}
\hline & \multirow{2}{*}{$\begin{array}{l}\text { Average } \\
\text { abnormal } \\
\text { returns (\%) }\end{array}$} & \multirow[t]{2}{*}{$t_{B M P}$} & \multirow{2}{*}{$\begin{array}{l}\text { Positive/ } \\
\text { Negative }\end{array}$} & \multicolumn{5}{|c|}{ Cumulativeaverage abnormal returns } \\
\hline & & & & $(-1,2)$ & $(-1,1)$ & $(0,1)$ & $(0,2)$ & $(1,2)$ \\
\hline $\mathrm{t}-2$ & 3.71 & 1.35 & $14 / 14$ & & & & & \\
\hline $\mathrm{t}-1$ & 3.45 & 0.90 & $11 / 17$ & $-3.50 \%$ & $-0.14 \%$ & $-3.59 \%$ & $-6.95 \%$ & $-4.35 \%$ \\
\hline Event day & -2.60 & -0.62 & $14 / 14$ & -1.15 & -0.15 & -1.00 & $-2.03 * *$ & $-2.38 * *$ \\
\hline $\mathrm{t}+1$ & -0.99 & -0.84 & $11 / 17$ & & & & & \\
\hline $\mathrm{t}+2$ & -3.36 & $-1.89 *$ & $12 / 16$ & & & & & \\
\hline
\end{tabular}

Panel C: market benchmark of S\&P 600 Food, Beverage, \& Tobacco Index

\begin{tabular}{|c|c|c|c|c|c|c|c|c|}
\hline & \multirow{2}{*}{$\begin{array}{l}\text { Average } \\
\text { abnormal } \\
\text { returns (\%) }\end{array}$} & \multirow[t]{2}{*}{$t_{B M P}$} & \multirow{2}{*}{$\begin{array}{l}\text { Positive/ } \\
\text { negative }\end{array}$} & \multicolumn{5}{|c|}{ Cumulative average abnormal returns } \\
\hline & & & & $(-1,2)$ & $(-1,1)$ & $(0,1)$ & $(0,2)$ & $(1,2)$ \\
\hline$t-2$ & 3.60 & 1.24 & $16 / 12$ & & & & & \\
\hline$t-1$ & 3.50 & 0.87 & $11 / 17$ & $-3.78 \%$ & $-0.17 \%$ & $-3.67 \%$ & $-7.28 \%$ & $-4.80 \%$ \\
\hline Event day & -2.48 & -0.55 & $12 / 16$ & -1.34 & -0.22 & -1.07 & $-2.24 * *$ & $-2.78^{* * *}$ \\
\hline$t+1$ & -1.19 & -1.09 & $12 / 16$ & & & & & \\
\hline$t+2$ & -3.61 & $-2.19 * *$ & $8 / 20$ & & & & & \\
\hline
\end{tabular}

This table displays the event study results around the court ruling against the Fourth Corner Credit Union. The average abnormal returns (AARs) correspond to the excess returns with respect to three different benchmarks. In panel A, the AARs are calculated against the zero-return benchmark; panel B uses the S\&P 500 Index as a broad market benchmark; panel $\mathrm{C}$ relies on the firms in the food, beverage, and tobacco industries, by using the S\&P 600 Food, Beverage, \& Tobacco Index as the market benchmark. Significance is calculated based on the two-sided parametric test by Boehmer et al. (1991). Column 3 displays the number of individual marijuana firms that have abnormal positive (negative) returns on the specific trading day. The cumulative average abnormal returns are calculated based on five different event windows

The $* * *, * *$, and $*$ represent significance at the $1 \%, 5 \%$, and the $10 \%$ levels 
Table 18 Event 2 with the non-parametric rank test by Corrado (1989) and Corrado and Zivney (1992)

Panel A: zero-return benchmark

\begin{tabular}{|c|c|c|c|c|c|c|c|c|}
\hline & \multirow{2}{*}{$\begin{array}{l}\text { Average } \\
\text { abnormal } \\
\text { returns (\%) }\end{array}$} & \multirow[t]{2}{*}{$t_{C}$} & \multirow{2}{*}{$\begin{array}{l}\text { Positive/ } \\
\text { no change/ } \\
\text { negative }\end{array}$} & \multicolumn{5}{|c|}{ Cumulative average abnormal returns } \\
\hline & & & & $(-1,2)$ & $(-1,1)$ & $(0,1)$ & $(0,2)$ & $(1,2)$ \\
\hline $\mathrm{t}-2$ & 3.44 & 1.01 & $13 / 6 / 9$ & & & & & \\
\hline $\mathrm{t}-1$ & 3.09 & 0.05 & $9 / 6 / 13$ & $-4.76 \%$ & $-0.92 \%$ & $-4.01 \%$ & $-7.85 \%$ & $-5.15 \%$ \\
\hline Event day & -2.70 & -0.61 & $11 / 4 / 13$ & $-1.69 *$ & -0.92 & -1.17 & $-1.98 * *$ & $-1.99 * *$ \\
\hline $\mathrm{t}+1$ & -1.31 & -1.04 & $6 / 6 / 16$ & & & & & \\
\hline $\mathrm{t}+2$ & -3.84 & $-1.77 *$ & $7 / 5 / 16$ & & & & & \\
\hline
\end{tabular}

Panel B: market benchmark of S\&P 500 Index

\begin{tabular}{lcrllllll}
\hline & $\begin{array}{l}\text { Average } \\
\text { abnormal } \\
\text { returns }(\%)\end{array}$ & $t_{C}$ & Positive/ & \multicolumn{5}{l}{ Cumulative average abnormal returns } \\
\cline { 5 - 8 } & & & negative & $(-1,2)$ & $(-1,1)$ & $(0,1)$ & $(0,2)$ & $(1,2)$ \\
\hline $\mathrm{t}-2$ & 3.71 & 1.07 & $14 / 14$ & & & & & \\
$\mathrm{t}-1$ & 3.45 & 0.24 & $11 / 17$ & $-3.50 \%$ & $-0.14 \%$ & $-3.59 \%$ & $-6.95 \%$ & $-4.35 \%$ \\
Event day & -2.60 & -0.53 & $14 / 14$ & -1.42 & -0.82 & -1.17 & $-1.78^{*}$ & $-1.81^{*}$ \\
$\mathrm{t}+1$ & -0.99 & -1.13 & $11 / 17$ & & & & & \\
$\mathrm{t}+2$ & -3.36 & -1.43 & $12 / 16$ & & & & & \\
\hline
\end{tabular}

Panel C: market benchmark of S\&P 600 Food, Beverage, \& Tobacco Index

\begin{tabular}{|c|c|c|c|c|c|c|c|c|}
\hline & \multirow{2}{*}{$\begin{array}{l}\text { Average } \\
\text { abnormal } \\
\text { returns }\end{array}$} & \multirow[t]{2}{*}{$t_{C}$} & \multirow{2}{*}{$\begin{array}{l}\text { Positive/ } \\
\text { Negative }\end{array}$} & \multicolumn{5}{|c|}{ Cumulative average abnormal returns } \\
\hline & & & & $(-1,2)$ & $(-1,1)$ & $(0,1)$ & $(0,2)$ & $(1,2)$ \\
\hline$t-2$ & 3.60 & 0.96 & $16 / 12$ & & & & & \\
\hline $\mathrm{t}-1$ & 3.50 & -0.02 & $11 / 17$ & $-3.78 \%$ & $-0.17 \%$ & $-3.67 \%$ & $-7.28 \%$ & $-4.80 \%$ \\
\hline Event day & -2.48 & -0.64 & $12 / 16$ & $-1.75^{*}$ & -0.98 & -1.19 & $-2.01 * *$ & $-2.01 * *$ \\
\hline $\mathrm{t}+1$ & -1.19 & -1.04 & $12 / 16$ & & & & & \\
\hline$t+2$ & -3.61 & $-1.80 *$ & $8 / 20$ & & & & & \\
\hline
\end{tabular}

This table displays the event study results around the court ruling against the Fourth Corner Credit Union. The average abnormal returns (AARs) correspond to the excess returns with respect to three different benchmarks. In panel A, the AARs are calculated against the zero-return benchmark; panel B uses the S\&P 500 Index as a broad market benchmark; panel $\mathrm{C}$ relies on the firms in the food, beverage, and tobacco industries, by using the S\&P 600 Food, Beverage, \& Tobacco Index as the market benchmark. Significance is calculated based on the non-parametric rank test by Corrado (1989) and Corrado and Zivney (1992). Column 3 displays the number of individual marijuana firms that have abnormal positive (negative) returns on the specific trading day. The cumulative average abnormal returns are calculated based on five different event windows

The ***,**, and * represent significance at the $1 \%, 5 \%$, and the $10 \%$ levels 


\section{Event 3: the SAFE Banking Act}

See Tables 19, 20 and 21.

Table 19 Event 3 with the standardized cross-sectional test by Kolari and Pynnönen (2010)

Panel A: zero-return benchmark

\begin{tabular}{|c|c|c|c|c|c|c|c|c|}
\hline & \multirow{2}{*}{$\begin{array}{l}\text { Average } \\
\text { abnormal } \\
\text { returns }(\%)\end{array}$} & \multirow[t]{2}{*}{$v$} & \multirow{2}{*}{$\begin{array}{l}\text { Positive/ } \\
\text { no change/ } \\
\text { negative }\end{array}$} & \multicolumn{5}{|c|}{ Cumulative average abnormal returns } \\
\hline & & & & $(-1,2)$ & $(-1,1)$ & $(0,1)$ & $(0,2)$ & $(1,2)$ \\
\hline $\mathrm{t}-2$ & 0.28 & 0.14 & $9 / 3 / 18$ & & & & & \\
\hline $\mathrm{t}-1$ & -2.64 & $-1.78 *$ & $4 / 4 / 22$ & $-6.26 \%$ & $-3.34 \%$ & $-0.70 \%$ & $-3.62 \%$ & $-5.92 \%$ \\
\hline Event day & 2.30 & 0.92 & $12 / 6 / 12$ & $-1.82 *$ & -0.99 & -0.32 & -1.56 & $-2.98 * * *$ \\
\hline $\mathrm{t}+1$ & -3.00 & $-2.06^{* *}$ & $5 / 6 / 19$ & & & & & \\
\hline $\mathrm{t}+2$ & -2.92 & $-3.02 * * *$ & $6 / 6 / 18$ & & & & & \\
\hline
\end{tabular}

Panel B: market benchmark of S\&P 500 Index

\begin{tabular}{|c|c|c|c|c|c|c|c|c|}
\hline & \multirow{2}{*}{$\begin{array}{l}\text { Average } \\
\text { abnormal } \\
\text { returns (\%) }\end{array}$} & \multirow[t]{2}{*}{$t_{K P}$} & \multirow{2}{*}{$\begin{array}{l}\text { Posi- } \\
\text { tive/ } \\
\text { negative }\end{array}$} & \multicolumn{5}{|c|}{ Cumulative average abnormal returns } \\
\hline & & & & $(-1,2)$ & $(-1,1)$ & $(0,1)$ & $(0,2)$ & $(1,2)$ \\
\hline $\mathrm{t}-2$ & 0.30 & 0.14 & $9 / 21$ & & & & & \\
\hline $\mathrm{t}-1$ & -2.05 & -1.33 & $8 / 22$ & $-5.56 \%$ & $-3.00 \%$ & $-0.95 \%$ & $-3.51 \%$ & $-5.39 \%$ \\
\hline Event day & 1.88 & 0.74 & $13 / 17$ & -1.54 & -0.85 & -0.42 & -1.46 & $-2.81 * * *$ \\
\hline $\mathrm{t}+1$ & -2.83 & $-1.98 * *$ & $7 / 23$ & & & & & \\
\hline $\mathrm{t}+2$ & -2.56 & $-2.74 * * *$ & $9 / 21$ & & & & & \\
\hline \multicolumn{9}{|c|}{ Panel C: market benchmark of S\&P 600 Food, Beverage, \& Tobacco Index } \\
\hline & \multirow{2}{*}{$\begin{array}{l}\text { Average } \\
\text { abnormal } \\
\text { returns }(\%)\end{array}$} & \multirow[t]{2}{*}{$t_{K P}$} & \multirow{2}{*}{$\begin{array}{l}\text { Positive/ } \\
\text { negative }\end{array}$} & \multicolumn{5}{|c|}{ Cumulative average abnormal returns } \\
\hline & & & & $(-1,2)$ & $(-1,1)$ & $(0,1)$ & $(0,2)$ & $(1,2)$ \\
\hline $\mathrm{t}-2$ & 0.20 & 0.09 & $9 / 21$ & & & & & \\
\hline $\mathrm{t}-1$ & -2.48 & -1.64 & $6 / 24$ & $-6.16 \%$ & $-3.45 \%$ & $-0.97 \%$ & $-3.68 \%$ & $-5.66 \%$ \\
\hline Event day & 1.98 & 0.77 & $14 / 16$ & $-1.73 *$ & -0.99 & -0.43 & -1.54 & $-2.93 * * *$ \\
\hline$t+1$ & -2.95 & $-2.06 * *$ & $7 / 23$ & & & & & \\
\hline$t+2$ & -2.71 & $-2.87 * * *$ & $8 / 22$ & & & & & \\
\hline
\end{tabular}

This table displays the event study results around the voting by the US House of Representatives on the SAFE Banking Act. The average abnormal returns (AARs) correspond to the excess returns with respect to three different benchmarks. In panel A, the AARs are calculated against the zero-return benchmark; panel B uses the S\&P 500 Index as a broad market benchmark; panel C relies on the SMEs in the food, beverage, and tobacco industries, by using the S\&P 600 Food, Beverage, \& Tobacco Index as the market benchmark. Significance is calculated based on the two-sided standardized cross-sectional test by Kolari and Pynnönen (2010). Column 3 displays the number of individual marijuana firms that have abnormal positive (negative) returns on the specific trading day. The cumulative average abnormal returns are calculated based on five different event windows

The ***, **, and * represent significance at the $1 \%, 5 \%$, and the $10 \%$ levels 
Table 20 Event 3 with the parametric test by Boehmer et al. (1991)

Panel A: zero-return benchmark

\begin{tabular}{|c|c|c|c|c|c|c|c|c|}
\hline & \multirow{2}{*}{$\begin{array}{l}\text { Average } \\
\text { abnormal } \\
\text { returns } \\
(\%)\end{array}$} & \multirow[t]{2}{*}{$t_{B M P}$} & \multirow{2}{*}{$\begin{array}{l}\text { Positive/ } \\
\text { no change/ } \\
\text { negative }\end{array}$} & \multicolumn{5}{|c|}{ Cumulative average abnormal returns } \\
\hline & & & & $(-1,2)$ & $(-1,1)$ & $(0,1)$ & $(0,2)$ & $(1,2)$ \\
\hline$t-2$ & 0.28 & -1.02 & $9 / 3 / 18$ & & & & & \\
\hline$t-1$ & -2.64 & $-2.98 * * *$ & $4 / 4 / 22$ & $-6.26 \%$ & $-3.34 \%$ & $-0.70 \%$ & $-3.62 \%$ & $-5.92 \%$ \\
\hline Event day & 2.30 & 0.91 & $12 / 6 / 12$ & $-2.78 * * *$ & $-2.08 * *$ & -0.97 & $-2.08 * *$ & $-2.46^{* *}$ \\
\hline$t+1$ & -3.00 & $-1.65^{*}$ & $5 / 6 / 19$ & & & & & \\
\hline$t+2$ & $-2.92 \%$ & $-3.04 * * *$ & $6 / 6 / 18$ & & & & & \\
\hline
\end{tabular}

Panel B: market benchmark of S\&P 500 Index

\begin{tabular}{|c|c|c|c|c|c|c|c|c|}
\hline & \multirow{2}{*}{$\begin{array}{l}\text { Average } \\
\text { abnormal } \\
\text { returns }(\%)\end{array}$} & \multirow[t]{2}{*}{$t_{B M P}$} & \multirow{2}{*}{$\begin{array}{l}\text { Positive/ } \\
\text { negative }\end{array}$} & \multicolumn{5}{|c|}{ Cumulative average abnormal returns } \\
\hline & & & & $(-1,2)$ & $(-1,1)$ & $(0,1)$ & $(0,2)$ & $(1,2)$ \\
\hline $\mathrm{t}-2$ & 0.30 & -1.01 & $9 / 21$ & & & & & \\
\hline $\mathrm{t}-1$ & -2.05 & $-2.49^{* *}$ & $8 / 22$ & $-5.56 \%$ & $-3.00 \%$ & $-0.95 \%$ & $-3.51 \%$ & $-5.39 \%$ \\
\hline Event day & 1.88 & 0.66 & $13 / 17$ & $-2.49 * *$ & $-1.90 *$ & -1.10 & $-1.99 * *$ & $-2.21 * *$ \\
\hline $\mathrm{t}+1$ & -2.83 & -1.56 & $7 / 23$ & & & & & \\
\hline$t+2$ & -2.56 & $-2.62 * * *$ & $9 / 21$ & & & & & \\
\hline \multicolumn{9}{|c|}{ Panel C: market benchmark of S\&P 600 Food, Beverage, \& Tobacco Index } \\
\hline & \multirow{2}{*}{$\begin{array}{l}\text { Average } \\
\text { abnormal } \\
\text { returns }(\%)\end{array}$} & \multirow[t]{2}{*}{$t_{B M P}$} & \multirow{2}{*}{$\begin{array}{l}\text { Positive/ } \\
\text { Nega- } \\
\text { tive }\end{array}$} & \multicolumn{5}{|c|}{ Cumulative average abnormal returns } \\
\hline & & & & $(-1,2)$ & $(-1,1)$ & $(0,1)$ & $(0,2)$ & $(1,2)$ \\
\hline $\mathrm{t}-2$ & 0.20 & -1.08 & $9 / 21$ & & & & & \\
\hline $\mathrm{t}-1$ & -2.48 & $-2.82 * * *$ & $6 / 24$ & $-6.16 \%$ & $-3.45 \%$ & $-0.97 \%$ & $-3.68 \%$ & $-5.66 \%$ \\
\hline Event day & 1.98 & 0.68 & $14 / 16$ & $-2.69 * * *$ & $-2.06^{* *}$ & -1.10 & $-2.08 * *$ & $-2.34 * *$ \\
\hline$t+1$ & -2.95 & -1.61 & $7 / 23$ & & & & & \\
\hline$t+2$ & -2.71 & $-2.79 * * *$ & $8 / 22$ & & & & & \\
\hline
\end{tabular}

This table displays the event study results around the voting by the US House of Representatives on the SAFE Banking Act. The average abnormal returns (AARs) correspond to the excess returns with respect to three different benchmarks. In panel A, the AARs are calculated against the zero-return benchmark; panel B uses the S\&P 500 Index as a broad market benchmark; panel C relies on the firms in the food, beverage, and tobacco industries, by using the S\&P 600 Food, Beverage, \& Tobacco Index as the market benchmark. Significance is calculated based on the two-sided parametric test by Boehmer et al. (1991). Column 3 displays the number of individual marijuana firms that have abnormal positive (negative) returns on the specific trading day. The cumulative average abnormal returns are calculated based on five different event windows

The ***,**, and * represent significance at the $1 \%, 5 \%$, and the $10 \%$ levels 
Table 21 Event 3 with the non-parametric rank test by Corrado (1989) and Corrado and Zivney (1992)

Panel A: zero-return benchmark

\begin{tabular}{|c|c|c|c|c|c|c|c|c|}
\hline & \multirow{2}{*}{$\begin{array}{l}\text { Average } \\
\text { abnormal } \\
\text { returns (\%) }\end{array}$} & \multirow[t]{2}{*}{$t_{C}$} & \multirow{2}{*}{$\begin{array}{l}\text { Positive/ } \\
\text { no change/ } \\
\text { negative }\end{array}$} & \multicolumn{5}{|c|}{ Cumulative averageabnormal returns } \\
\hline & & & & $(-1,2)$ & $(-1,1)$ & $(0,1)$ & $(0,2)$ & $(1,2)$ \\
\hline $\mathrm{t}-2$ & 0.28 & -0.87 & $9 / 3 / 18$ & & & & & \\
\hline $\mathrm{t}-1$ & -2.64 & $-2.28 * *$ & $4 / 4 / 22$ & $-6.26 \%$ & $-3.34 \%$ & $-0.70 \%$ & $-3.62 \%$ & $-5.92 \%$ \\
\hline Event day & 2.30 & 0.28 & $12 / 6 / 12$ & $-2.28 * *$ & $-1.77 *$ & -0.56 & -1.32 & $-1.82 *$ \\
\hline $\mathrm{t}+1$ & -3.00 & -1.07 & $5 / 6 / 19$ & & & & & \\
\hline $\mathrm{t}+2$ & -2.92 & -1.50 & $6 / 6 / 18$ & & & & & \\
\hline
\end{tabular}

Panel B: market benchmark of S\&P 500 Index

\begin{tabular}{|c|c|c|c|c|c|c|c|c|}
\hline & \multirow{2}{*}{$\begin{array}{l}\text { Average } \\
\text { abnormal } \\
\text { returns }(\%)\end{array}$} & \multirow[t]{2}{*}{$t_{C}$} & \multirow{2}{*}{$\begin{array}{l}\text { Positive/ } \\
\text { negative }\end{array}$} & \multicolumn{5}{|c|}{ Cumulative average abnormal returns } \\
\hline & & & & $(-1,2)$ & $(-1,1)$ & $(0,1)$ & $(0,2)$ & $(1,2)$ \\
\hline $\mathrm{t}-2$ & 0.30 & -1.07 & $9 / 21$ & & & & & \\
\hline $\mathrm{t}-1$ & -2.05 & $-2.49 * *$ & $8 / 22$ & $-5.56 \%$ & $-3.00 \%$ & $-0.95 \%$ & $-3.51 \%$ & $-5.39 \%$ \\
\hline Event day & 1.88 & 0.06 & $13 / 17$ & $-2.58 * *$ & $-2.11 * *$ & -0.82 & -1.54 & $-1.92^{*}$ \\
\hline$t+1$ & -2.83 & -1.22 & $7 / 23$ & & & & & \\
\hline$t+2$ & -2.56 & -1.50 & $9 / 21$ & & & & & \\
\hline
\end{tabular}

Panel C: market benchmark of S\&P 600 Food, Beverage, \& Tobacco Index

\begin{tabular}{|c|c|c|c|c|c|c|c|c|}
\hline & \multirow{2}{*}{$\begin{array}{l}\text { Average abnor- } \\
\text { mal returns }(\%)\end{array}$} & \multirow[t]{2}{*}{$t_{C}$} & \multirow{2}{*}{$\begin{array}{l}\text { Positive/ } \\
\text { negative }\end{array}$} & \multicolumn{5}{|c|}{ Cumulative average abnormal returns } \\
\hline & & & & $(-1,2)$ & $(-1,1)$ & $(0,1)$ & $(0,2)$ & $(1,2)$ \\
\hline $\mathrm{t}-2$ & 0.20 & -0.92 & $9 / 21$ & & & & & \\
\hline$t-1$ & -2.48 & $-2.42 * *$ & $6 / 24$ & $-6.16 \%$ & $-3.45 \%$ & $-0.97 \%$ & $-3.68 \%$ & $-5.66 \%$ \\
\hline $\begin{array}{r}\text { Event } \\
\text { day }\end{array}$ & 1.98 & 0.20 & $14 / 16$ & $-2.44 * *$ & $-1.94^{*}$ & -0.67 & -1.42 & $-1.88^{*}$ \\
\hline $\mathrm{t}+1$ & -2.95 & -1.15 & $7 / 23$ & & & & & \\
\hline $\mathrm{t}+2$ & -2.71 & -1.51 & $8 / 22$ & & & & & \\
\hline
\end{tabular}

This table displays the event study results around the voting by the US House of Representatives on the SAFE Banking Act. The average abnormal returns (AARs) correspond to the excess returns with respect to three different benchmarks. In panel A, the AARs are calculated against the zero-return benchmark; panel B uses the S\&P 500 Index as a broad market benchmark; panel C relies on the firms in the food, beverage, and tobacco industries, by using the S\&P 600 Food, Beverage, \& Tobacco Index as the market benchmark. Significance is calculated based on the non-parametric rank test by Corrado (1989) and Corrado and Zivney (1992). Column 3 displays the number of individual marijuana firms that have abnormal positive (negative) returns on the specific trading day. The cumulative average abnormal returns are calculated based on five different event windows

The $* * *, * *$, and $*$ represent significance at the $1 \%, 5 \%$, and the $10 \%$ levels 


\section{Appendix 4: Robustness tests: survey results}

See Tables 22, 23, 24, 25 and 26.

Table 22 Financial transaction management with respondents that at least have worked 1 year for the surveyed firms

Panel A: handling of financial transactions

\begin{tabular}{|c|c|c|c|c|}
\hline & \multicolumn{2}{|c|}{ Marijuana firms } & \multicolumn{2}{|c|}{ Microbreweries } \\
\hline & \multicolumn{2}{|c|}{$\left[\mathrm{N}=35^{\mathrm{a}}\right]$} & \multicolumn{2}{|c|}{$[\mathrm{N}=23]$} \\
\hline & $\mathrm{N}$ & $\mathrm{In} \%$ & $\mathrm{~N}$ & $\mathrm{In} \%$ \\
\hline \multicolumn{5}{|c|}{ How do you receive most of your revenue? } \\
\hline Cash & 23 & 66 & 1 & 4 \\
\hline Check & 12 & 34 & 4 & 17 \\
\hline Via a bank & 2 & 6 & 18 & 78 \\
\hline Via a non-bank (e.g., Bitcoin) & 0 & 0 & 0 & 0 \\
\hline \multicolumn{5}{|l|}{ How do you pay most of your bills? } \\
\hline Check & 13 & 37 & 9 & 39 \\
\hline Cash & 13 & 37 & 0 & 0 \\
\hline Via a bank & 13 & 37 & 14 & 61 \\
\hline Via a non-bank (e.g., Bitcoin) & 0 & 0 & 0 & 0 \\
\hline
\end{tabular}

Panel B: access to banking of marijuana firms

\section{Marijuana firms}

\begin{tabular}{ll}
\hline $\mathrm{N}=42]$ \\
$\mathrm{N}$ & $\mathrm{In} \%$
\end{tabular}

Does your firm currently have a bank account?

$\begin{array}{lll}\text { Yes, directly } & 25 & 60 \\ \text { Yes, indirectly (e.g., private account) } & 8 & 19 \\ \text { No } & 9 & 21 \\ \text { Perceived stability of bank relationship } & & \\ \text { Long-term } & 21 & 64 \\ \text { Short-term } & 9 & 27 \\ \text { Terminable } & 3 & 9\end{array}$

Did the bank reject or close your account?

$\begin{array}{lll}\text { Yes } & 25 & 63 \\ \text { No } & 15 & 38\end{array}$

Panel A of this table displays the responses on the handling of money transactions by marijuana firms and microbreweries. We report how firms receive revenues and pay their bills. In panel B, we report how many marijuana firms currently have bank accounts and how often bank accounts were closed as well as their perceived stability of the banking relationship. Note that for some questions we received multiple answers

${ }^{a}$ Multiple answers possible 
Table 23 Benefits of access to electronic payment services via banks with respondents that at least have worked 1 year for the surveyed firms

\begin{tabular}{lllllll}
\hline Row & Benefits & Mean score $\begin{array}{l}\% \text { with } 4 \\
\text { or 5 score }\end{array}$ & $\begin{array}{l}\text { N } \\
\text { Significant } \\
\text { differences in } \\
\text { mean score vs. } \\
\text { rows }\end{array}$ & $\begin{array}{l}\text { H0: Mean score } \\
=3\end{array}$ \\
\hline$(1)$ & Reduced risks & 4.26 & $77 \%$ & 35 & $2-5$ & $* * *$ \\
$(2)$ & Reduced time & 3.60 & $54 \%$ & 35 & 1 & $* *$ \\
$(3)$ & More satisfied customers & 3.60 & $63 \%$ & 35 & 1,5 & $* *$ \\
$(4)$ & Reduced costs & 3.54 & $54 \%$ & 35 & 1 & $* *$ \\
$(5)$ & More satisfied suppliers & 3.03 & $46 \%$ & 35 & 1,3 &
\end{tabular}

This table reports the survey responses on the benefits of access to electronic payment services offered by banks. Respondents were asked to indicate the level of importance on a scale of 1 (not at all beneficial) to 5 (very beneficial). Column 3 reports the mean score where higher values correspond to larger benefits. Column 4 presents the percent of respondents who indicated the beneficial levels of 4 or 5 (somewhat beneficial and very beneficial). Column 5 displays the number of respondents. Column 6 reports the result of a t test of the null hypothesis that the mean score for a given benefit is equal to the mean score for each of the other benefits, where only significant differences at the $5 \%$ level are reported. Column 7 reports the $t$ test of the null hypothesis that each mean score is equal to three (neither beneficial nor not beneficial)

The $* * *$ and $* *$ indicate statistical significance at the $1 \%$ and $5 \%$ levels, respectively 
Table 24 Bank loans and credit lines with respondents that at least have worked 1 year for the surveyed firms

Panel A: financing sources of marijuana firms

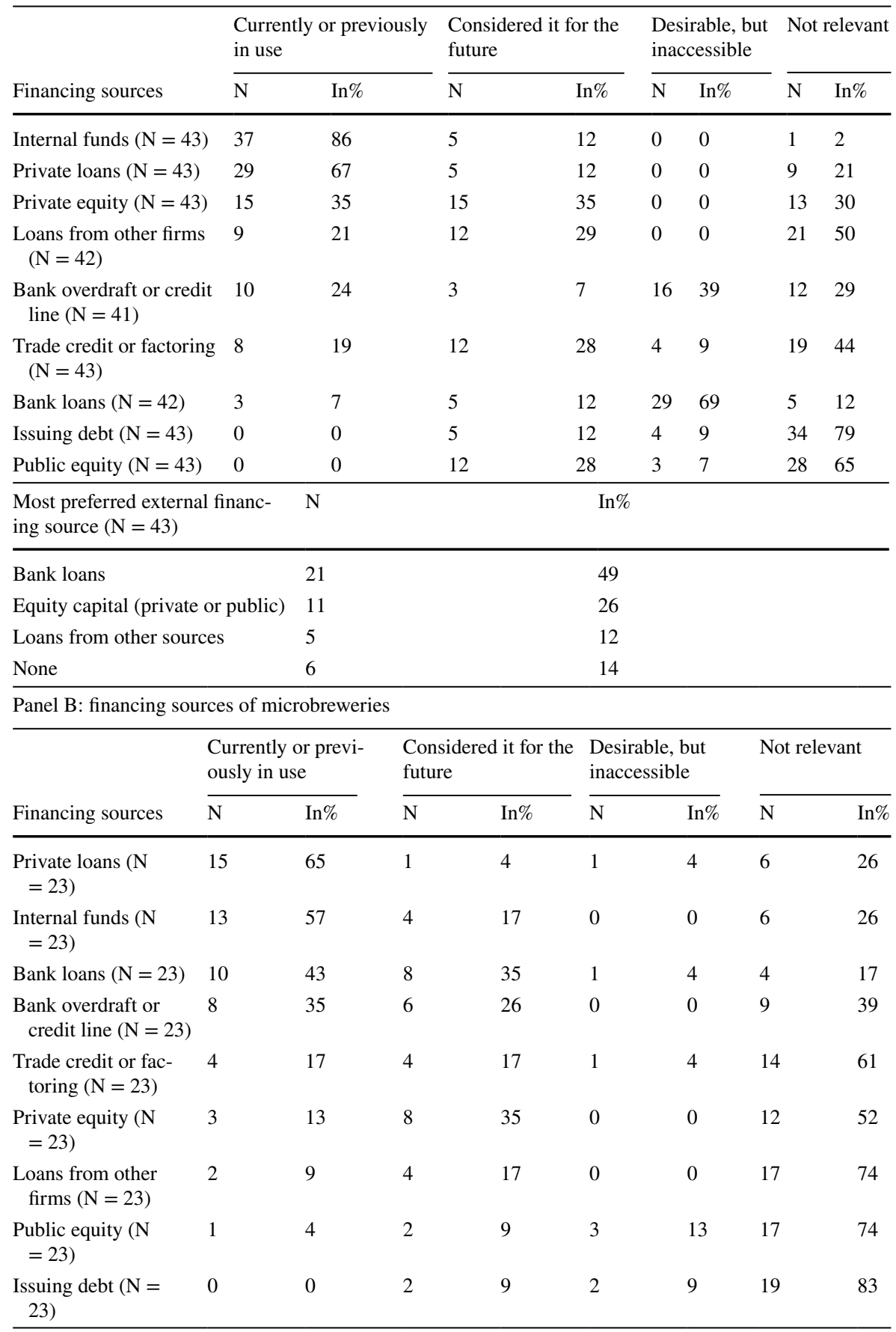


Table 24 (continued)

Panel C: financial constraints of marijuana firms and microbreweries

\begin{tabular}{|c|c|c|c|c|}
\hline \multirow[b]{2}{*}{$\begin{array}{l}\text { Reaction in case of } \\
\text { unexpected costs }\end{array}$} & \multicolumn{2}{|c|}{ Marijuana firms } & \multicolumn{2}{|c|}{ Microbreweries } \\
\hline & $\mathrm{N}=43$ & $\operatorname{In} \%$ & $\mathrm{~N}=23$ & $\operatorname{In} \%$ \\
\hline Raising capital & 24 & 56 & 17 & 74 \\
\hline $\begin{array}{l}\text { Cut back invest- } \\
\text { ments }\end{array}$ & 8 & 19 & 3 & 13 \\
\hline $\begin{array}{l}\text { Delay payments of } \\
\text { suppliers }\end{array}$ & 5 & 12 & 2 & 9 \\
\hline Lay off employees & 3 & 7 & 0 & 0 \\
\hline $\begin{array}{l}\text { Increase the price } \\
\text { of products }\end{array}$ & 2 & 5 & 0 & 0 \\
\hline \multirow[t]{3}{*}{$\begin{array}{l}\text { Delay wage pay- } \\
\text { ments }\end{array}$} & 1 & 2 & 1 & 4 \\
\hline & \multicolumn{2}{|c|}{ Marijuana firms } & \multicolumn{2}{|c|}{ Microbreweries } \\
\hline & \multicolumn{2}{|l|}{$\mathrm{N}=44$} & \multicolumn{2}{|l|}{$\mathrm{N}=24$} \\
\hline $\begin{array}{l}\text { Restricting growth } \\
\text { opportunities }\end{array}$ & $\mathrm{N}$ & $\operatorname{In} \%$ & $\mathrm{~N}$ & $\operatorname{In} \%$ \\
\hline Yes & 32 & 73 & 6 & 26 \\
\hline No & 12 & 27 & 17 & 74 \\
\hline
\end{tabular}

This table reports the survey responses related to the financing of marijuana firms and microbreweries. Panels A and B display several financing sources that are used, considered, or desired by the firms. Panel $\mathrm{C}$ shows the first reaction in case of unexpected costs for marijuana firms and microbreweries. It further shows whether these firms see themselves as financially constrained 


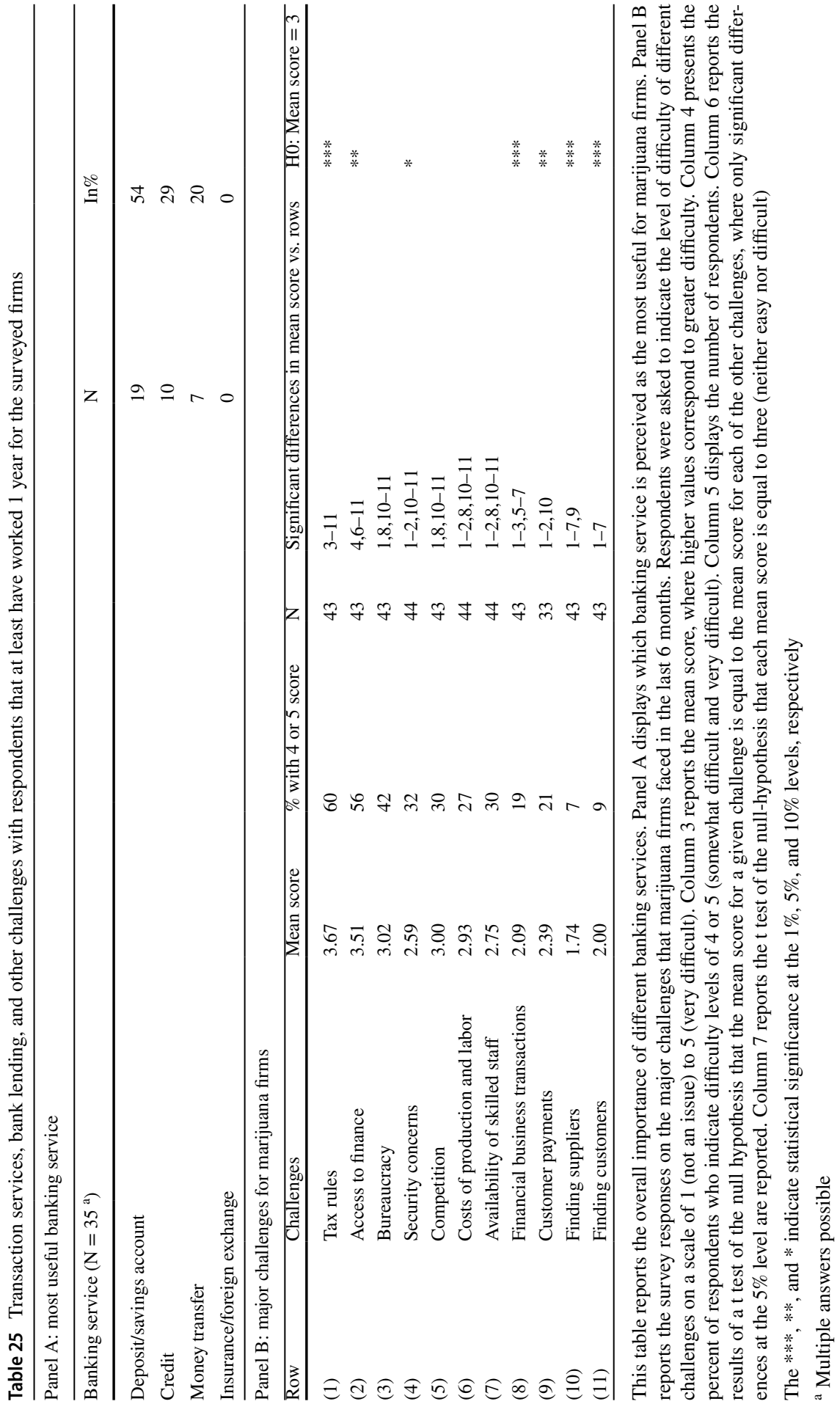


Table 26 Comparisons for challenges of marijuana SMEs and microbreweries with respondents that at least have worked 1 year for the surveyed firms

\begin{tabular}{|c|c|c|c|c|c|}
\hline \multirow[t]{2}{*}{ Challenges } & \multicolumn{2}{|c|}{ Marijuana firms } & \multicolumn{2}{|c|}{ Microbreweries } & \multirow{2}{*}{$\begin{array}{l}\text { H0: } \\
\text { equality of } \\
\text { means }\end{array}$} \\
\hline & Mean & St. dev & Mean & St. dev & \\
\hline Tax rules & 3.67 & 1.49 & 3.00 & 1.13 & $* *$ \\
\hline Access to finance & 3.51 & 1.44 & 2.74 & 1.63 & $*$ \\
\hline Bureaucracy & 3.02 & 1.41 & 3.17 & 1.23 & \\
\hline Security concerns & 2.59 & 1.35 & 1.74 & 0.81 & $* * *$ \\
\hline Competition & 3.00 & 1.13 & 2.78 & 1.28 & \\
\hline Costs of production and labor & 2.93 & 1.17 & 2.91 & 1.20 & \\
\hline Availability of skilled staff & 2.75 & 1.24 & 2.30 & 1.02 & \\
\hline Financial business transactions & 2.09 & 1.38 & 1.74 & 1.25 & \\
\hline Customer payments & 2.39 & 1.37 & 1.35 & 0.57 & $* * *$ \\
\hline Finding suppliers & 1.74 & 1.05 & 1.30 & 0.63 & $* *$ \\
\hline Finding customers & 2.00 & 1.05 & 2.30 & 1.11 & \\
\hline
\end{tabular}

This table reports the mean score and standard deviation of survey responses on the major challenges that marijuana firms and microbreweries faced in the last 6 months. Respondents were asked to indicate the level of difficulty of different challenges on a scale of 1 (not an issue) to 5 (very difficult). The last column reports the result of a Welch $t$ test of equal means between the two different firm groups

The ***,**, and * indicate a statistical significance difference in means at the $1 \%, 5 \%$, and $10 \%$ levels, respectively

\section{Event studies' results for the subgroup of eight firms that is examined in all events}

See Fig. 4. 


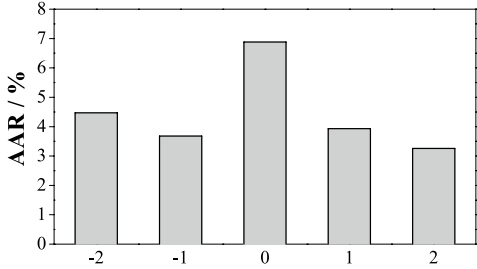

(a) Event 1: Zero-return benchmark

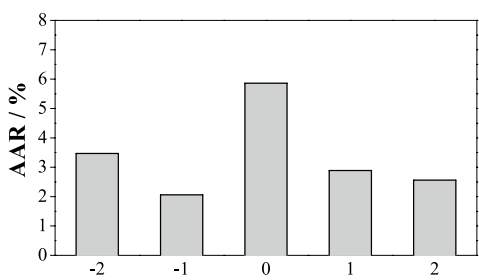

(c) Event 1: Market benchmark of S\&P 600 Food, Beverages, \& Tobacco Index

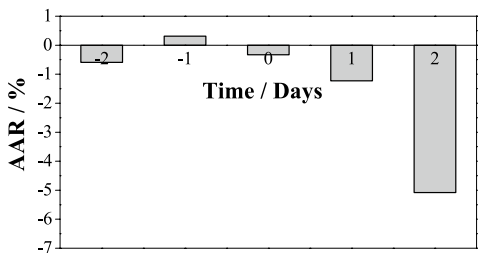

(e) Event 2: Market benchmark of S\&P 500 Index

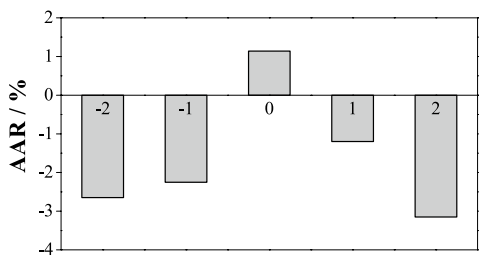

(g) Event 3: Zero-return benchmark

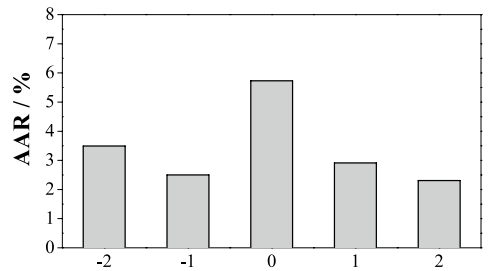

(b) Event 1: Market benchmark of S\&P 500 Index

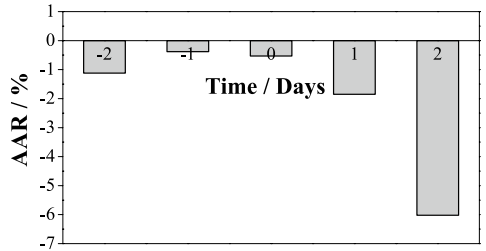

(d) Event 2: Zero-return benchmark

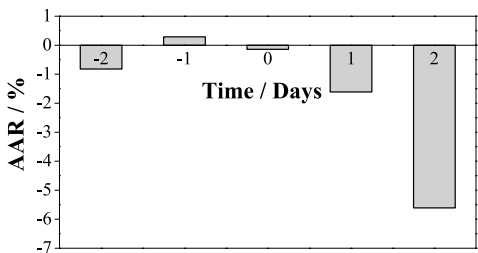

(f) Event 2: Market benchmark of S\&P 600 Food, Beverages, \& Tobacco Index

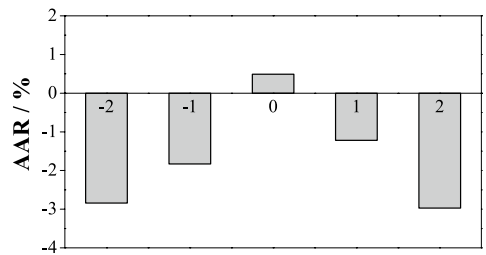

(h) Event 3: Market benchmark of S\&P 500 Index

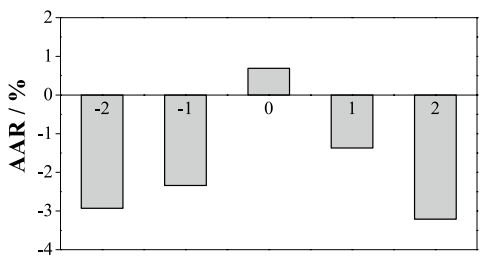

(i) Event 3: Market benchmark of S\&P 600 Food, Beverages, \& Tobacco Index

Fig. 4 Event studies' results for the subgroup of eight firms that is examined in all events 
Acknowledgements This paper was partly written during a stay of the first author at Cass Business School, London. We thank Thorsten Beck, Tobias Berg, Christoph Börner, Martin Brown, Ulf Brüggemann, Hans-Peter Burghof, Marc Deloof, Patrick Kampkötter, Werner Neus, Markus Nisch, Anh D. Pham, Andreas Pfingsten, Marc S. Rapp, David T. Robinson, Zacharias Sautner, Anna Staerz, Matthias Sutter, Theresa Veer, Laurent Weill, audiences at the Entrepreneurial Financial Management Conference 2017, Academy of Entrepreneurial Finance (Europe) Conference 2017, World Finance Conference 2017, Research Seminar of Rotterdam University 2017, Münsteraner Bankenworkshop 2017, the Finance Research Workshop of Cass Business School 2018, the HERMES Franco-German Doctoral Seminar 2019, three anonymous reviewers and the managing editor (Wolfgang Breuer) for very helpful and constructive comments.

Funding Open Access funding enabled and organized by Projekt DEAL.

\section{Compliance with ethical standards}

Conflict of interest The authors declare that they have no conflict of interest.

Open Access This article is licensed under a Creative Commons Attribution 4.0 International License, which permits use, sharing, adaptation, distribution and reproduction in any medium or format, as long as you give appropriate credit to the original author(s) and the source, provide a link to the Creative Commons licence, and indicate if changes were made. The images or other third party material in this article are included in the article's Creative Commons licence, unless indicated otherwise in a credit line to the material. If material is not included in the article's Creative Commons licence and your intended use is not permitted by statutory regulation or exceeds the permitted use, you will need to obtain permission directly from the copyright holder. To view a copy of this licence, visit http://creativecommons.org/licen ses/by/4.0/.

\section{References}

Almeida H, Campello M, Weisbach MS (2004) The cash flow sensitivity of cash. J Finance 59(4):17771804. https://doi.org/10.1111/j.1540-6261.2004.00679.x

Almeida H, Campello M (2007) Financial constraints, asset tangibility, and corporate investment. Rev Financial Stud 20(5):1429-1460. https://doi.org/10.1093/rfs/hhm019

Altman A (2014) Holder: banks should be able to handle pot money. https://swampland.time. com/2014/01/24/signs-of-a-big-shift-on-u-s-marijuana-regulation/print/. Accessed 8 Apr 2019

Anhalt BD (2016) Crafting a model state law for today's beer industry. Roger Williams Univ Law Rev 21:162. https://heinonline.org/hol-cgi-bin/get_pdf.cgi?handle=hein.journals/rwulr21\&section=9

Ayyagari M, Demirgüç-Kunt A, Maksimovic V (2008) How important are financing constraints? The role of finance in the business environment. World Bank Econ Rev 22(3):483-516. https://doi. org/10.1093/wber/lhn018

Ayyagari M, Demirguc-Kunt A, Maksimovic V (2013) Financing in developing countries. In: Constantinides GM, Harris M, Stulz RM (eds) Handbook of the economics of finance, vol 2. Elsevier, New York, pp 683-757

Beck T, Demirgüç-Kunt A, Maksimovic V (2005) Financial and legal constraints to growth: does firm size matter? J Finance 60(1):137-177. https://doi.org/10.1111/j.1540-6261.2005.00727.x

Beck T, Demirgüç-Kunt A, Maksimovic V (2008) Financing patterns around the world: are small firms different? J Financial Econ 89(3):467-487. https://doi.org/10.1016/j.jfineco.2007.10.005

Beck T, Pamuk H, Ramrattan R, Uras B (2018) Payment instruments, finance and development. J Dev Econ 133:162-186. https://doi.org/10.1016/j.jdeveco.2018.01.005

Berg T (2018) Got rejected? Real effects of not getting a loan. Rev Financial Stud 31(12):4912-4957. https://doi.org/10.1093/rfs/hhy038

Berger E, Seegert N (2020) Half banked: the real effects of financial exclusion on firms. Unpublished Working Paper, Cornell University 
Berger AN, Udell GF (1998) The economics of small business finance: the roles of private equity and debt markets in the financial growth cycle. J Ban Finance 22(6-8):613-673. https://doi.org/10.1016/ S0378-4266(98)00038-7

Bernanke B (2008) Remarks at the economic club of New York. Stabilizing the financial markets and the economy. https://www.federalreserve.gov/newsevents/speech/bernanke20081015a.htm. Accessed 8 Apr 2019

Bertrand M, Mullainathan S (2001) Do people mean what they say? Implications for subjective survey data. Am Econ Rev 91(2):67-72. https://doi.org/10.1257/aer.91.2.67

Bertrand M, Schoar A, Thesmar D (2007) Banking deregulation and industry structure: evidence from the French banking reforms of 1985. J Finance 62(2):597-628. https://doi.org/10.111 1/j.1540-6261.2007.01218.x

Bhue G (2018) Government certification, financial access, and growth: evidence from the US marijuana industry. Unpublished Working Paper, The University of Chicago

Boehmer E, Masumeci J, Poulsen AB (1991) Event-study methodology under conditions of eventinduced variance. J Financial Econ 30(2):253-272. https://doi.org/10.1016/0304-405X(91)90032-F

Brewers Association (2017) Steady growth for small and independent brewers. https://www.brewersass ociation.org/press-releases/2016-growth-small-independent-brewers. Accessed 8 Apr 2019

Brown SJ, Warner JB (1985) Using daily stock returns: the case of event studies. J Financial Econ 14(1):3-31. https://doi.org/10.1016/0304-405X(85)90042-X

Business Marijuana, Daily ${ }^{\mathrm{TM}}$, (2016) Chart of the week: breakdown of interest rates for friends \& family loans in the cannabis industry. https://mjbizdaily.com/chart-week-breakdown-interest-rates-friendsfamily-loans-cannabis-industry/. Accessed 8 Apr 2019

Chiang J (2017) Banking access strategies for cannabis-related businesses. http://www.treasurer.ca.gov/ cbwg/resources/reports/110717-cannabis-report.pdf. Accessed 8 Apr 2019

Cole JM (2011) Memorandum from James M. Cole, Deputy Attorney Gen., to United States attorneys. Guidance regarding the Ogden Memo in jurisdictions seeking to authorize marijuana for medical use. www.justice.gov/sites/default/files/oip/legacy/2014/07/23/dag-guidance-2011-for-medicalmarijuana-use.pdf. Accessed 8 Apr 2019

Cole JM (2014) Memorandum for all United States attorneys. Guidance regarding marijuana related financial crimes. www.dfi.wa.gov/documents/banks/guidance-marijuana-related-business.pdf. Accessed 8 Apr 2019

Corrado CJ (1989) A nonparametric test for abnormal security-price performance in event studies. J Financial Econ 23(2):385-395. https://doi.org/10.1016/0304-405X(89)90064-0

Corrado CJ, Zivney TL (1992) The specification and power of the sign test in event study hypothesis tests using daily stock returns. J Financial Quant Anal 27(3):465-478. http://www.jstor.org/stable/2331331

Credit Union National Association (2016) Inside Washington. https://news.cuna.org/articles/109018-insid e-washington. Accessed 8 Apr 2019

Demirgüç-Kunt A, Maksimovic V (1998) Law, finance, and firm growth. J Finance 53(6):2107-2137. https://doi.org/10.1111/0022-1082.00084

Department of the Treasury Financial Crimes Enforcement Network (2014) BSA expectations regarding marijuana-related businesses. https://www.fincen.gov/sites/default/files/shared/FIN-2014-G001.pdf. Accessed 8 Apr 2019

Donaldson JR, Piacentino G, Thakor A (2018) Warehouse banking. J Financial Econ 129(2):250-267. https://doi.org/10.1016/j.jfineco.2018.04.011

Durand RB, Koh S, Limkriangkrai M (2013) Saints versus sinners. Does morality matter? J Int Financ Mark Inst Money 24:166-183. https://doi.org/10.1016/j.intfin.2012.12.002

Elzinga KG, Tremblay CH, Tremblay VJ (2015) Craft beer in the United States: history, numbers, and geography. J Wine Econ 10(3):242-274. https://doi.org/10.1017/jwe.2015.22

Fracassi C, Garmaise MJ, Kogan S, Natividad G (2016) Business microloans for US subprime borrowers. J Financial Quant Anal 51(1):55-83. https://doi.org/10.1017/S0022109016000144

Hall BH (2008) The financing of innovation. In: Shane S (ed) Handbook of technology and innovation management. Wiley, New York, pp 409-429

Hill JA (2015) Banks, marijuana, and federalism. Case Western Reserve Law Rev 65(3):597-647. https:// heinonline.org/HOL/P?h=hein.journals/cwrlrv65\&i=637

Hong H, Kacperczyk M (2009) The price of sin: the effects of social norms on markets. J Financial Econ 93(1):15-36. https://doi.org/10.1016/j.jfineco.2008.09.001

Huber K (2018) Disentangling the effects of a banking crisis: evidence from German firms and counties. Am Econ Rev 108(3):868-98. https://doi.org/10.1257/aer.20161534 
Jack W, Suri T (2014) Risk sharing and transactions costs: evidence from Kenya's mobile money revolution. Am Econ Rev 104(1):183-223. https://doi.org/10.1257/aer.104.1.183

Jayaratne J, Strahan PE (1996) The finance-growth nexus: evidence from bank branch deregulation. Q J Econ 111(3):639-670. https://doi.org/10.2307/2946668

Kohn M (1999) Early deposit banking. Working Paper 99-3, Dartmouth College

Kolari JW, Pynnönen S (2010) Event study testing with cross-sectional correlation of abnormal returns. Rev Financial Stud 23(11):3996-4025. https://doi.org/10.1093/rfs/hhq072

Koptis S (2016) Why China's growth could be over. CNBC. www.cnbc.com/2016/01/05/why-china s-growth-could-be-over-commentary.html. Accessed 8 Apr 2019

Krishnan K, Nandy DK, Puri M (2014) Does financing spur small business productivity? Evidence from a natural experiment. Rev Financial Stud 28(6):1768-1809. https://doi.org/10.1093/rfs/hhu087

Kysucky V, Norden L (2015) The benefits of relationship lending in a cross-country context: a metaanalysis. Manag Sci 62(1):90-110. https://doi.org/10.1287/mnsc.2014.2088

Lawrence G (2019) Marijuana industry financial services: obstacles and solutions. Industry Report, Reason Foundation

Levine R (1997) Financial development and economic growth: views and agenda. J Econ Lit 35(2):688726. https://www.jstor.org/stable/2729790

Levine R (2005) Finance and growth: theory and evidence. In: Aghion P, Durlauf SN (eds) Handbook of economic growth, vol 1. Elsevier, New York, pp 865-934. https://doi.org/10.1016/S1574 $-0684(05) 01012-9$

Levine R, Loayza N, Beck T (2000) Financial intermediation and growth: causality and causes. J Monet Econ 46(1):31-77. https://doi.org/10.1016/S0304-3932(00)00017-9

MacKinlay AC (1997) Event studies in economics and finance. J Econ Lit 35(1):13-39. https://www.jstor .org/stable/2729691

Marijuana Business Daily ${ }^{\mathrm{TM}}$ (2015) Marijuana business factbook, 3rd edn. Marijuana Business Daily ${ }^{\mathrm{TM}}$

Marijuana Business Daily ${ }^{\mathrm{TM}}$ (2019) Annual Marijuana Business Factbook, 7th edn. Marijuana Business Daily ${ }^{\mathrm{TM}}$

Mills K, McCarthy B (2016) The state of small business lending: Credit access during the recovery and how technology may change the game. Working paper 17-042, Harvard Business School

NBC NEWS (2016) Stocks battered for second time in 2016 as China, energy weigh. www.nbcnews.com/ business/markets/stocks-battered-second-time-2016-china-energy-weigh-n491606. Accessed 8 Apr 2019

Plyler MG, Haas S, Nagarajan G (2010) Community-level economic effects of M-Pesa in Kenya. Iris Center report, University of Maryland

Robb AM, Robinson DT (2014) The capital structure decisions of new firms. Rev Financial Stud 27(1):153-179. https://doi.org/10.1093/rfs/hhs072

Song F, Thakor AV (2010) Financial system architecture and the co-evolution of banks and capital markets. Econ J 120(547):1021-1055. https://doi.org/10.1111/j.1468-0297.2009.02345.x

Stavins J (2018) Consumer preferences for payment methods: role of discounts and surcharges. J Bank Finance 94:35-53. https://doi.org/10.1016/j.jbankfin.2018.06.013

Vaughan P (2007) Early lessons from the deployment of M-Pesa. Vodaphones's own mobile transactions service. In: The Transformational Potential of M-transactions, Vodaphone Policy Paper Series, No 6. https://www.vodaphone.com/m-transactions

Ventura A, Koenitzer M, Stein P, Tufano P, Drummer D (2015) The future of fintech: a paradigm shift in small business finance. Report, World Economic Forum, Global Agenda Council on the Future of Financing and Capital., http://www3.weforum.org/docs/IP/2015/FS/GAC15_The_Future_of_FinTe ch_Paradigm_Shift_Small_Business_Finance_report_2015.pdf. Accessed 8 Apr 2019

Weisskopf JP (2019) Breaking bad: an investment in cannabis. Finance Res Lett. https://doi.org/10.1016/j. frl.2019.05.019 (Forthcoming)

Publisher's Note Springer Nature remains neutral with regard to jurisdictional claims in published maps and institutional affiliations. 